\title{
Decomposing EPP effects in Greek enclisis
}

\author{
Marios Mavrogiorgos* \\ University of Cambridge \\ mm476@cam.ac.uk
}

\begin{abstract}
This paper pursues the idea, originally proposed by Landau (2007), that the Extended Projection Principle is PF related on the basis of Greek enclisis. It is argued that the complementary distribution pattern attested with Cypriot Greek finite enclisis derives from the fact that the first head $\mathrm{H}$ c-selecting т $\mathrm{P}$ has a morpho-syntactic requirement, and a related $\mathrm{PF} /$ prosodic requirement subject to an Economy Condition. The former derives merger of an X or XP copy at $\mathrm{H}$, while the latter ensures that only one of the two copies gets spelled-out. Non-finite $\mathrm{H}$ triggers obligatory enclisis in both Cypriot and Standard Greek, as it contains only affixal morphemes, which is further supported by Medieval Greek non-finite enclisis. The parameterization of $\mathrm{H}$ along with potential implications are also discussed.
\end{abstract}

\section{Keywords}

Cypriot Greek - Standard Greek - Medieval Greek - Extended Projection Principle enclisis - proclisis - Tobler-Mussfaia Law - complementizer - finiteness

* For helpful comments and discussion, at various stages of this work, I wish to thank Yoryia Agouraki, Elena Anagnostopoulou, Idan Landau, Winnie Lechner, Marika Lekakou, Arhonto Terzi, as well as the audience at the workshop on the morpho-syntax of Modern Greek dialects, ICGL12 (Freie Universität Berlin). Moreover, I would like to thank two anonymous reviewers as well as the editor of the present volume whose written comments and suggestions enabled me to improve the manuscript. The usual disclaimers apply.

(C) MARIOS MAVRogiorgos, 2017 | DOI: 10.1163/15699846-01702004

This is an open access article distributed under the terms of the prevailing CC-BY-NC license 


\section{Introduction ${ }^{1}$}

The nature of the Extended Projection Principle (EPP) (see, e.g., Chomsky 1981 and subsequent literature) has always been controversial within generative linguistics. In this paper, I argue that an approach according to which the EPP is only partially morpho-syntactic in nature (see Landau 2007) is in a better position to account for the complicated facts of finite enclisis in Cypriot Greek (CG). An example illustrating the finite enclisis pattern is provided in (1) below:

\section{(1) a. Lalí mu to pkiós?}

Say.3.SG 1.SG.DAT 3.N.SG.ACC who.NOM

b. *Mu to lalí pkiós?

c. Pkiós mu to lali?

Who.NOM 1.SG.DAT 3.N.SG.ACC say.3.SG

d. *Pkiós lalí mu to?

'Who is saying it to me?'

As shown in (1), in the presence of clitics, either the verb or a preverbal quantifier has to appear in clause-initial position in order for the sentence to be grammatical. Crucially, though, these two strategies are in complementary distribution, as illustrated in (1d).

In what follows I show that this characteristic pattern, found in all ToblerMussafia languages (i.e. languages with finite enclisis), only concerns constituents which merge (for independent morpho-syntactic reasons) within a particular clausal area. This area (highlighted in (2) in bold) immediately extends the XP containing the clitic and the verb:

\section{(2) $\left[_{\mathrm{CP} 3} \mathrm{C}_{3}\left[_{\mathrm{TopP}} \operatorname{Top}\left[_{\mathrm{CP} 2} \mathrm{C}_{2}\left[{ }_{\text {FocusP }} /{ }_{\mathrm{WhP}}\right.\right.\right.\right.$ Focus $/ \mathrm{Wh}\left[_{\mathrm{CP} 1} \mathrm{C}_{1}\left[_{\mathrm{NegP}} \operatorname{Neg}\left[_{\mathrm{XP}} \ldots\{\mathrm{CL}, \mathrm{V}\}\right.\right.\right.$ ...][]]]]]]}

In particular, I argue that when a constituent X or XP is merged within the said area, $\mathrm{V}$-merger to a head higher than the cliticization site is blocked $\left({ }^{*} \mathrm{~V}\right)$. This correlates with proclisis:

1 All data used in this paper are taken or adapted from the literature referenced within the text, or elicited from native speakers. Whenever necessary, the exact source is provided next to the example. 


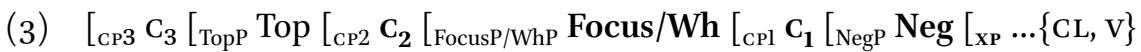
...]]]]]]]

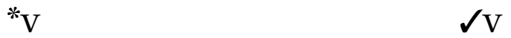

On the other hand, if no X or XP is realized/merged, then (finite) enclisis obtains through merger of $\mathrm{v}$ across the cliticization site $(\checkmark \mathrm{v})$ :

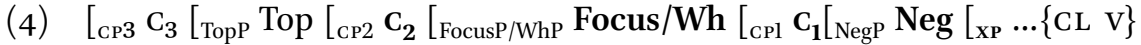
...]]]]]]]

$\checkmark \mathrm{V}$

${ }^{*} \mathrm{~V}$

I argue that this distribution follows from a phonological/spell-out requirement imposed on an Agreeing functional head $\mathrm{H}$ with the following properties: $\mathrm{H} \mathrm{c}$-selects TP/INFLP (= XP in (2-4) above) and is structurally and functionally defined, although crucially not in terms of feature content (i.e. $\mathrm{H}$ is subject to a 'decomposed EPP', following the hypothesis put forward by Landau 2007 that the EPP is (also) PF in nature):

(5) a. $\left[\ldots\left[{ }_{\mathrm{HP}} \mathbf{H}\left[{ }_{\mathrm{TP}} \mathrm{TP}\left[{ }_{\mathrm{vP}} \cdots \mathrm{V} \ldots\right]\right]\right]\right]$

b. $\mathbf{H}=\left\{\mathrm{f}_{1} ; \mathrm{f}_{2} ; \ldots \mathrm{f}_{\mathrm{n}}\right\}$ and feature projection is subject to $\mathrm{f}_{1}>\mathrm{f}_{2}>\ldots \mathrm{f}_{\mathrm{n}}$

(5) specifies that $\mathrm{H}$ has a morpho-syntactic feature that needs checking. It also specifies that $\mathrm{H}$ may come in flavours (i.e. it may contain different types of features), where insertion and projection of each feature is regulated by a feature projection algorithm of some sort (which may or may not be reducible to independent semantico-syntactic restrictions). Besides this morpho-syntactic requirement, there is an additional $\mathrm{PF}$ requirement imposed on $\mathrm{H}$, namely its Edge must be realized by material with phonological content:

(6) $\quad\left[\mathrm{HP} \operatorname{Spec}\left[\mathrm{H}^{\prime} H_{[+ \text {feature }}\left[\mathrm{YP}_{\mathrm{YP}} \mathrm{WP}\right.\right.\right.$ Y ZP $\left.\left.]\right]\right]$

AGREE

Given that the Edge of a projection is taken to include both the head and the spec, ${ }^{2}$ and assuming that this requirement, being an interface requirement, is

2 Note that this definition of the Edge would carry over to a Phonological domain $\mathrm{x}$, as long as the relevant projection lies at the Edge of $\mathrm{x}$ (see Pesetsky 1998; Selkirk 2011; and sections 3.2.2 and 4.2). 
restricted by Economy, realization of either the head or the spec must be sufficient, and therefore required (see also Collins 2007; Koopman 2000; Kupula 2011; Nchare \& Terzi 2014; Pearson 2005; Pesetsky 1998). This is illustrated in (7).

(7)

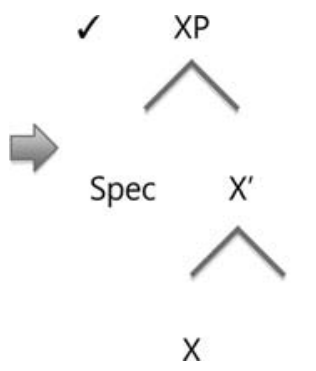

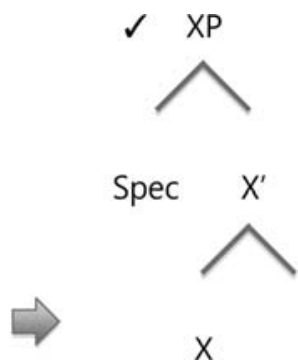

I argue that it is exactly the Economy restriction in (7) that gives rise to the complementary distribution pattern illustrated in (1) above. I further show that obligatory non-finite enclisis in CG (and Standard Greek (sG)) also involves an Edge Requirement imposed on $\mathrm{H}$, however in this particular case an additional affixal requirement, independently imposed on $\mathrm{H}$ within Morphology, blocks the complementary distribution. This fact supports the idea that the PF requirement is prosodic in nature (as morphology cancels out (7) as long as (6) is satisfied). Finally, I argue that finite enclisis is not found in languages like SG due to the fact that $\mathrm{H}$ is parameterized.

This paper is structured as follows: section 2 gives the theoretical background and introduces the notion of the EPP adopted in this paper. Section 3 offers a detailed presentation of finite enclisis in CG (and of enclisis in CG and SG more generally). Section 4 provides an analysis of the data based on EPP decomposition. Section 5 concludes the discussion.

\section{$2 \quad$ Theoretical background}

Researchers have been disagreeing whether the EPP constitutes a theoretical primitive, whether it should be reduced to independent principles such as case or agreement, or whether it should be considered an epiphenomenon and hence abandoned altogether (see e.g. Grohmann et al. 2000; Landau 2007; Lasnik 2003 for an overview). But, what is the EPP? Initially, the EPP was taken to be a grammatical rule ensuring that a finite clause has an overt subject. Within Government and Binding (GB) Theory, this would translate into the requirement that finite $\mathrm{T} / \mathrm{AGR}$ projects an overt specifier (at least in languages like English): 
(8) a. $\left[{ }_{\mathrm{TP}} *(\mathrm{John})\left[\mathrm{T}_{\mathrm{T}} \mathrm{T}[\mathrm{vp}\right.\right.$ sleeps $\left.\left.]\right]\right]$.

[Finite T]

b. $\left[{ }_{\mathrm{TP}}\right.$ John decided $\left[{ }_{\mathrm{CP}}\left[{ }_{\mathrm{TP}}\left({ }^{*}\right.\right.\right.$ Mary $){ }_{\mathrm{T}^{\prime}}$ to $\left[{ }_{\mathrm{vp}}\right.$ sleep $\left.\left.\left.\left.]\right]\right]\right]\right]$.

[Non-finite T]

Nowadays, this view has changed considerably. First of all, most researchers agree that the EPP applies to any functional head (e.g. C, T, v, n, p) (see, e.g., Chomsky 2000, 2001). This follows from the assumption that the EPP is some sort of feature ((non-)categorical, or of a more generalized nature) that is added to one or more morpho-syntactic features, the latter typically being taken to reside within a functional head $\mathrm{F}$ (e.g. phi features). The role of the EPP, then, is to trigger overt displacement of an agreeing constituent to F. Moreover, it is standardly assumed that: (a) satisfaction of the EPP may be parameterized, in that languages may differ in whether a head $\mathrm{X}$ or a phrase XP can satisfy the EPP at $\mathrm{F}$ (see, e.g., Alexiadou \& Anagnostopoulou 1998 for V-to-T movement in pro drop languages satisfying a D-feature on $\mathrm{T}$ ); (b) the X or XP satisfying the EPP may be phonologically overt or covert (e.g. PRO or pro), as what is at issue is merger of an abstract feature bundle.

Despite the general consensus that the EPP has a morpho-syntactic basis, it has been pointed out that the EPP is directly related to a semantic and/or PF effect, on empirical and theoretical grounds (see Landau 2007: Introduction for an overview). Landau (2007) goes one step further and argues (on the basis of various empirical phenomena traditionally attributed to the ECP, as well as cases of null-headed specifiers) that the EPP has properties which clearly differentiate it from other morpho-syntactic features in terms of a number of parameters, including locality and headedness. In particular, he proposes that the EPP is a selectional $\mathrm{PF} /[\mathrm{p}]$ feature which is parasitic on some morphosyntactic feature. This PF feature must be satisfied (at PF) via the spell-out of (the head of) an appropriate (morpho-syntactic) copy (i.e. a copy which satisfies locality and headedness). ${ }^{3}$ PF approaches to the EPP have also been proposed by other researchers (e.g. Holmberg 2000; Manzini \& Savoia 2002; Richards 2016; Roberts \& Roussou 2002; Sigurđsson 2010).

If the EPP involves a PF requirement, one issue that arises is how to model it within current theories of the syntax-PF interface. This would include, among others, the use of a PF diacritic in syntax (which would instruct PF to realize a certain feature (bundle)), as well as the nature of PF (e.g. can PF move items, or does it only have a filtering role? See Bošković 2001 for a comparison

3 A reviewer asks what position Landau takes concerning the classic version of the EPP (see (8) above). As far as I understand Landau (2007), the classic EPP would be a subcase of [p] feature satisfaction on $\mathrm{T}$ by a local overt head or (head of a) spec. 
of various possible syntax-PF interface models; see also Landau 2007; Pesetsky 1998; Richards 2010, 2016). Although it is not as yet clear whether it is feasible, theoretically and empirically, to have a purely PF requirement or not, what most researchers agree on is that PF should be as restricted as possible. A second question revolves around any possible realizational interactions between an XP and an X merged at a certain functional head. In particular, it has been pointed out in the literature that cross-linguistically the spec and head of a projection need not (and, by economy, must not) be realized phonologically at the same time (although one of them must be spelled-out; see, e.g., Speas 1995). This restriction is more generally known as the doubly filled Comp filter (see Chomsky \& Lasnik 1977); however, it is found in other domains besides the CP, as illustrated in (9-12) below:

CP domain (Pesetsky 1998)

(9) a. ${ }^{*}\left[{ }_{D P}\right.$ The $\operatorname{man}\left[{ }_{\mathrm{CP}}\right.$ who $\left[{ }_{\mathrm{C}^{\prime}} \mathrm{C}\right.$ that $\left[{ }_{\mathrm{IP}}\right.$ I saw (who) $\left.\left.\left.]\right]\right]\right]$.

b. The man who I saw.

c. The man that I saw.

[English]

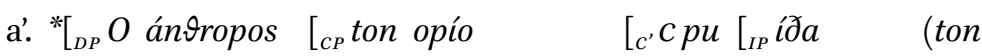
the man.Nom the whom.M.ACc that see.PsT.1.SG (the opio)]]]]. whom.M.ACC)

b. O ánЭropos ton opío iða.

c.. O ánЭropos pu iða.

'The man who/that I saw.'

$\mathrm{T}(\mathrm{P})$ domain [pro drop] (Alexiadou \& Anagnostopoulou 1998)

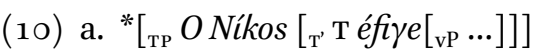

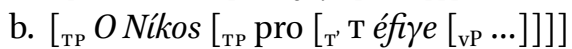

c. $\left[{ }_{\mathrm{TP}}\left[{ }_{\mathrm{T}^{\prime}}\right.\right.$ T Éfije $\left[{ }_{\mathrm{vP}}\right.$ o Níkos $\left.\left.]\right]\right]$

v(P) domain [clitic doubling] (Alexiadou \& Anagnostopoulou 1997; Kupula 2011; Sportiche 1992/1998)

(11) a. * ${ }_{\mathrm{vp}}$ Ton Níko $\left[{ }_{\mathrm{vp}}\right.$ pro $\left[{ }_{\mathrm{v}} \mathrm{v} \mathrm{v} \mathrm{v}\right.$ ton $i ð e\left[{ }_{\mathrm{vp}}\left[\mathrm{V}_{\mathrm{v}}{ }^{\prime}(\mathrm{v})(\right.\right.$ ton $)($ ton Níko) $\left.\left.\left.\left.]\right]\right]\right]\right]$

b. [ ${ }_{\mathrm{vP}}$ pro $\left[\mathrm{v}^{\prime} \mathrm{v}-\mathrm{v}\right.$ ton $i ð e\left[{ }_{\mathrm{vp}}\left[\mathrm{v}^{\prime}(\mathrm{v})(\right.\right.$ ton $)$ ton Níko] $\left.\left.]\right]\right]$ 
$\mathrm{P}(\mathrm{P})$ domain [r-pronouns in English] (Collins 2007; Nchare \& Terzi 2014)

(12) a. * $\left[\right.$ I went $\left[\mathrm{PP}\right.$ there $\left[\mathrm{P}^{\prime}\right.$ to $\mathrm{P}$ (there) $\left.\left.]\right]\right]$

b. $\left[\right.$ I went $\left[\mathrm{PP}\right.$ there $\left[\mathrm{P}^{\prime} \varnothing \mathrm{P}(\right.$ there $\left.\left.\left.)\right]\right]\right]$

[English]

This pattern involves complementary distribution, strict locality (i.e. the $\mathrm{x}$ or XP must spell out $\mathrm{F}$ locally), and wide distribution (i.e. it applies (to a certaintypically higher-head) across functional domains). ${ }^{4}$

In what follows I propose that enclisis in CG and SG also falls within the realm of the EPP, as described above. Such an approach groups enclisis together with phenomena such as pro drop, doubly-filled comp filter effects, clitic doubling, stylistic fronting, as well as that-trace effects, in the sense that they all involve a complementary distribution of phonologically realized constituents that are in a local structural relationship.

\section{$3 \quad$ Enclisis in CG and SG}

\subsection{Overview}

I start the discussion by giving an overview of (linear) enclisis in CG and SG (for phonological proclisis/enclisis, see Klavans 1985; for CG, see Revithiadou 2006, 2007. For descriptions of CG enclisis, see Agouraki 1997, 2001, 2010; Chatzikyriakidis 2010, 2012; Condoravdi \& Kiparsky 2001; Mavrogiorgos 2010, 2013; Pappas 2004; Philippaki-Warburton 1995, 1998; Revithiadou 2006, 2007; Rivero 1994; Rivero \& Terzi 1995; Terzi 1999a,b). The main generalization to keep in mind is the following: in SG, enclisis strictly correlates with lack of person and/or restricted person specification on the verbal host (see Mavrogiorgos 2010). In CG, on the other hand, enclisis correlates with properties of the left periphery of the clause, and only residually with lack of person and/or restricted person on the verbal host.

More specifically, in SG a clitic (cluster) immediately precedes or follows the verbal host, depending on the finiteness properties of the latter:

4 Moreover, it seems to differ from criterial effects (see Rizzi 1996), where both the spec and the head of a projection are realized overtly (although, crucially, they do not have to). This may be the case because the relevant spec and head do not get spelled out within the same phrase, or because languages with criterial effects allow for feature bundling (hence, the spec and head each realize a distinct feature at the same location). This is an issue open for further research. 
(13) a. O Jánis tin ayapái ti María. the Janis.NOM 3.F.SG.ACC love.3.SG the Maria.ACC 'John loves her, Mary.'

b. Jáni, aүápa tin ti María! John.voc love.IPFV.IM P.2.SG 3.F.SG.ACC the Maria.ACC 'John, love Mary!'

CG also has obligatory enclisis with non-finite verbal hosts:
(14) a. Esí
Эkiávasè
to!
you.voc read.PFV.IMP.2.SG 3.N.SG.ACC
'You read it!'

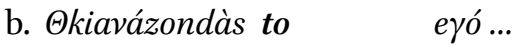 reading 'I, reading it ...'

With finite verbal hosts, however, CG has enclisis, which is the default situation:

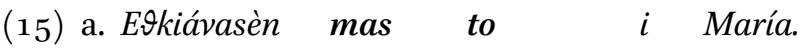
read.PST.3.SG 1.PL.DAT 3.N.SG.ACC the Maria.NOM 'Mary read it to us.'

b. Eqkiávasèn mas to i María? read.PST.3.SG 1.PL.DAT 3.N.SG.ACC the Maria.NOM 'Did Maria read it to us?'

Proclisis typically arises if some preverbal constituent of a particular type $c$ commands the finite CL V cluster. Depending on the phrase structure status of the c-commanding constituent, the following sub-cases can be distinguished (see also Mavrogiorgos 2013 for Tobler-Mussafia languages more generally) (preverbal constituents are in italics; clitics are in bold):

\subsubsection{The c-commanding constituent is an $X P$}

Typically, this sub-type involves either operator phrases and/or stressed phrases (including wh-phrases, verum focus phrases, and contrastive focus phrases). ${ }^{5}$ Note that if the relevant XP does not c-command the CL V cluster, enclisis obtains:

5 Preverbal negative phrases (which are typically stressed) also trigger proclisis. However, they 


\section{(16) a. Pkiós to eףkiávasen? who.NOM 3.N.SG.ACC read.PST.3.sG 'Who read it?'}

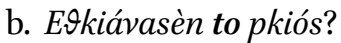
'Read it who?'
c. Tí tu éðokes?
what.ACC 3.M.SG.DAT give.PST.2.SG 'What did you give him?'

d. Éðokès tu tí?

'You gave him what?' [subject wh-phrase]
a. ЕГÓ to
éðoka,
oi $i \quad$ María.
I.NOM 3.N.SG.ACC give.PST.1.SG, not the Maria.NOM

[stressed subject phrase]

b. Éðokà to Егó, oi i María.

[stressed subject phrase in situ] 'I gave it, not Mary.'

also require the presence of a negation particle (negative concord), which immediately precedes the CL V cluster and which independently triggers proclisis (as cases with postverbal negative phrases (ii) reveal):

(i) Típota en mu éðoke.

nothing NEG 1.SG.DAT give.PST.3.SG

(ii) En ти éðoke típota.

'S/he did not give me anything.'

As they are not revealing, negative phrases are not discussed in this paper. On the other hand, (i) poses a potential complication for the approach defended here: if both en and típota merge at $\mathrm{H}$ and get spelled out there, this would contradict the Economy Condition in (7). In this respect, note that it is likely that típota is spelled out in the spec of a separate Focus head (cf. that it is obligatorily stressed). Alternatively, we could assume that the non-affixal status of the negative particle enforces spell-out of $\mathrm{H}$ in the presence of an overt spec (i.e. Morphology overrides the Prosodic Constraint, the latter only being subject to the Economy Condition (and see also section 4.3)). Which option is the right one is an issue open for research. 
c. TÚto mu éðoke.

[stressed object phrase]

THIS.ACC 1.SG.DAT give.PST.3.SG

d. Éðokè mu TÚto.

'THIS is what s/he gave me.'

[stressed object phrase in situ]

(18) a. kaLÁ to lalún.

[stressed adverb]

WELL 3.N.SG.ACC say.3.PL

b. Lalún to kaLÁ.

'They say it correctly'.

[stressed adverb in situ]

Note that there are certain preverbal XPs that give rise to enclisis. These XPS (which include D-linked wh-phrases (19d) (see Revithiadou 2006: 83 (her 4b'))) are typically interpreted as topics and must be cliticized when they function as objects. Note that contrastive topics (19e) are typically stressed, which means that the presence of a stressed preverbal XP is not a sufficient condition for proclisis:

(19) a. I María ípen mu óti... [subject topic] the Maria.NOM say.PST.3.SG 1.SG.DAT that ... 'Mary told me that ...'

b. Tsinu ipen $\quad$ tu $\quad i \quad$ María oti... that.one.DAT say.PST.3.SG 3.M.SG.DAT the Maria.NOM that 'That one, Mary told him that ...'

[IO topic]

c. Túto ipen to to $i$ María. [Do topic] this.ACC say.PST.3.sG 3.M.SG.DAT 3.N.SG.ACC the Maria.NoM 'This, Mary said it to him.'

d. Pjós pu úlus tus anthrópus eףkiávasèn to? who.NOM from all the people.PL.ACC read.PST.3.SG 3.N.SG.ACC

[D-linked subject wh-phrase]

'Which one of all the people read it?'

e. Tu Kósta éðokà tu mávro vivlío, the Kósta.DAT give.PST.1.SG 3.M.SG.DAT the black.ACC book.ACC 
tse tis Marías éðokà tis to áspro.

and the María.DAT give.PST.1.sG 3.F.SG.DAT the white.ACC

[Contr topic]

'As for Kostas, I gave him the black covered book, and as for Maria, I gave her the white covered one.'

3.1.2 The c-commanding constituent is an $X$

This sub-type typically involves preverbal particles such as negation and modality markers, or alternatively certain complementizers.

(20) a. En to íksera.

[negation particle]

NEG 3.N.SG.ACC know.PST.1.SG

'I did not know it.'

b. đélo na sas po túto.

want.1.SG SUBJV 2.PL.DAT say.1.SG this.ACC

[subjunctive particle; embedded]

'I want to tell you this.'

c. $\mathrm{Na}$ sas po túto. [subjunctive particle; main] SUBJV 2.PL.GEN say.1.SG this.ACC

'Allow me to tell you this.'

d. Énna sas po túto.

[future particle]

FUT 2.PL.DAT say.1.SG this.ACC

'I will tell you this.'

e. Pérki su to féri. [modality marker] maybe 2.SG.DAT 3.N.SG.ACC bring.3.SG

'Maybe s/he will bring it to you.'

f. Ipen pos/óti ${ }^{6}$ to éfere $i$ María. [Comp] say.PST.3.SG that it.N.SG.ACC bring.PST.3.SG the Maria.NOM 'S/he said that Maria brought it.'

6 I will return to the specifics of the complentizer óti (and of similar complementizers) later on in the paper (see 3.2.2). 
g. Éfl pollús anঐrópus pu tin ksérun. [Comp] have.3.SG many.ACC people.ACC that 3.F.SG.ACC know.3.PL 'There are many people that know her.'

h. En kséro an ton arapái $i$ María. [Comp] NEG know.1.SG whether 3.M.sG.ACc love.3.sG the Maria.NOM 'I do not know whether Mary loves him.'

i. Áma me ¿ðe $i$ Maria... when 1.SG.ACC see.PST.3.SG the Maria.Nom 'When Maria saw me ...'

3.1.3 Two or more c-commanding constituents:

An important question is what happens when there are more than one preverbal constituents present. The following patterns apply: (i) when both an $X$ and (at least) one $X P$ precede the clitic (cluster), it is the closest c-commanding constituent that determines the position of the clitic (cluster) in relation to the verbal host:

(21) a. Ípen óti tu éðoken to vivlío $i$ say.PST.3.SG that 3.M.SG.DAT give.PST.3.SG the book.ACC the María. [Comp] Maria.NoM

'S/he said that Mary gave him the book.'

b. Ípen óti $i$ María édokèn tu to say.PST.3.SG that the Maria.NOM give.PST.3.SG 3.M.SG.DAT the vivlío.

book.ACC

[Comp; topic] 'S/he said that Mary gave him the book.'

c. Ípen óti $\quad$ esí tu to édokes say.PST.3.SG that 2.SG.NOM 3.M.SG.DAT 3.N.SG.ACC give.PST.2.SG to vivlio, oi $i$ María. [Comp; stressed phrase] the book.ACC not the Maria.NOM

'S/he said that it was you that gave the book to him, not Mary'

In (21a) a complementizer immediately precedes the clitic (cluster) and triggers proclisis. When a preverbal subject topic intervenes between the same complementizer and the clitic (cluster) (cf. 21b), enclisis obtains. When the 
intervening phrase is a stressed pronominal subject (as in 21c), proclisis obtains. What these examples show is that the proclisis effect of a complementizer can be cancelled out in the presence of an intervening phrase that normally triggers enclisis.

The same principle applies when (at least) two XPs precede the clitic (cluster): it is the XP closest to the clitic (cluster) which determines the position of the clitic. Consider the following sentences:

(22) a. Pkiós tin ¿ðe ti María? [wh-phrase] who.NOM 3.F.SG.ACC see.PST.3.SG the Maria.ACC 'Who saw Mary?'

b. Ti María ¿ðen tin pkiós? [topic] the Maria.ACC see.PST.3.SG 3.F.SG.ACC who.NOM 'As for Mary, who did you say saw her?'

c. Ti María pkiós tin ¿ðe? [topic $>>$ wh-phrase] the Maria.ACC who.NOM 3.F.SG.ACC see.PST.3.SG 'Mary, who saw her?'

d. O Nikólas emílisèn tis. the Nicholas.NOM talk.PST.3.SG 3.F.SG.DAT 'Nicholas talked to her.'

e. Tis Marías o Nikólas emílisèn tis. [topic ${ }_{1}>$ topic $_{2}$ ] the Maria.DAT the Nicholas.NOM talk.PST.3.SG 3.F.SG.DAT 'As for Mary, Nicolas talked to her.'

f. $O$ Nikólas tis Marías emílisèn tis. [topic ${ }_{2}>$ topic $_{1}$ ] the Nicholas.Nom the Mary.DAT talk.PST.3.SG 3.F.SG.DAT 'As for Mary, Nicholas talked to her.'

g. Tis Marías esí tis emílises. the Maria.DAT YOU.NOM 3.F.SG.DAT talk.PST.2.SG 'As for Mary, it was You who talked to her.'

[topic $>>$ stressed phrase]

While a preverbal wh-phrase triggers proclisis (22a), a preverbal topic phrase triggers enclisis $(22 b)$. The crucial piece of data is $(22 c)$ : here a wh-phrase triggers proclisis even though it is preceded by a preverbal topic, which suggests 
that it is the XP closest to the clitic-cluster (in this case, the wh-phrase) that determines the position of the clitic. ${ }^{7}$ The same effect is illustrated with preverbal topics $(22 \mathrm{~d}-\mathrm{f})$, which trigger enclisis, and with an intervening stressed phrase (22g), which triggers proclisis.

To summarize, in this section I have shown that, unlike SG, in CG the position of the clitic before or after the verbal host typically correlates with the spell-out position of certain preverbal CP-related XPs and/or Xs (and only residually with the person specification on the verbal host).

\subsection{Patterns in the data: the EPP-like distribution of finite enclisis ${ }^{8}$}

\subsubsection{Preverbal XPs and modality/negation Xs}

In this section I argue that the CG data described earlier have the EPP distribution (see sections 1 and 2), in that enclisis only shows up whenever the specifier or head of a certain functional head is not independently spelled out.

By way of reminder, CG has proclisis when some preverbal operator and/or stressed XP (23a), or some preverbal Comp/Modal/Neg head (23b) c-commands the CL V cluster, otherwise it has enclisis $(23 \mathrm{c})$ :

(23) a. $\mathbf{X P} \mathbf{P}_{[\text {Focus } / \text { wH }]}$ CL V

b. $\mathbf{X}_{[\mathrm{Comp} / \mathrm{Mod} / \mathrm{Neg}]} \mathrm{CL} \mathrm{V}$

c. \# $[\mathrm{V}$ CL $]$

On the other hand, a Topic XP gives rise to enclisis, and the same applies to certain complementizers:

(24) a. $\mathbf{X P}_{[\text {Topic }]}$ V CL

b. $\mathbf{X}_{[\text {Comp }]} \mathrm{V}$ CL

There are two main interesting facts regarding (23) and (24): first, the proclisisenclisis alternation seems to correlate with various types of features, which do not constitute a natural class, morpho-syntactically and/or semanti-

7 Note that the opposite order (namely, wh-phrase >> topic) is suboptimal in CG:

?*Pkiós ti María ið̃e tin?

For this reason, it is not possible to test this order against the hypothesis put forward here.

8 This section was restructured following suggestions made by the editor, who is hereby acknowledged. 
cally. ${ }^{9}$ Second, all these features are typically considered to be projected above the phrase where the CL V cluster is located, i.e. at the CP-TP border. Leaving the first issue aside for the moment (but see section 4 below), it would be useful to see whether the projections hosting the relevant features form some kind of contiguous domain or not. In this regard, Rizzi's (1997) cartographic enterprise (and much subsequent work after that) offers us a useful localization tool.

In particular, Rizzi (1997) has pointed out that cross-linguistically Topics are generally merged higher than preverbal focused/stressed phrases and/or whphrases. It has been shown by various researchers (see e.g. Iatridou 1991; Anagnostopoulou 1997; Roussou 2000, among many others) that this also applies to SG, and the same seems to be the case also for CG, given the data presented in section 3.1 (and see the following sentences which illustrate the fact that the reverse order is ungrammatical): 10
$(25)$
a. Tu Kósta tí $\quad t u \quad$ édokes?
the Kosta.DAT what.ACC
3.M.SG.DAT give.PST.2.SG

9 To illustrate with one example, there is no single operation that we know of which is contingent on the presence of a (non-wh) comp or a wh-operator.

10 Note that $\mathrm{D}$-linked wh-phrases behave like other preverbal topics in that they trigger enclisis and may co-occur with other topics (iii-iv). However, the fact that a D-linked whphrase cannot co-occur along with a wh-phrase (i) (as opposed to non-wh topics, which can (ii)), suggests that at some point during the derivation the D-linked wh-phrase must be in WhP/Foc:

(i) *Pjós pu úlus tus mathités póte to eqkiávasen? who.Nom from all the students.ACC when 3.N.SG.ACC read.PST.3.sG ‘*Which one of all the students when read it?'

(ii) Túto to vivlío póte to eঐkiávasen? this.ACC the book.ACC when 3.N.SG.ACC read.PST.3.SG 'This book, when did s/he read it?'

(iii) Túto to vivlío pjós $p u$ úlus tus mathités ełkiávasèn this.ACC the book.ACC who.NOM from all the students.ACC read.PST.3.SG to?

3.N.SG.ACC

'This book, which one of all the students read it?'

(iv) Pjós pu úlus tus mathités túto to vivlío eもkiávasèn to? 
b. *Títu Kósta éðokes tu? 'What did you give to Kostas'?

c. Tu Kósta túto tu éðoka. the Kosta.DAT THIS.ACC 3.M.SG.DAT give.PST.1.SG

d. *TÚTo tu Kósta éðoka tu.

'To Kostas, THIS is what I gave him.'

Moreover, negation and modal particles are merged lower than preverbal foci or wh-phrases in SG (see Roussou 2000 and references therein), and the same applies to $\mathrm{CG}$, as illustrated below:

(26) a. Tu Kósta pkiós na min tu to the Kosta.DAT who.NOM SUBJV NEG 3.M.SG.DAT 3.N.SG.ACC ðóki? give.3.SG 'To Kostas, who should not give it to him?'

b. Tu Kósta pkiós énna tu to Jóki? the Kosta.DAT who.NOM FUT 3.M.SG.DAT it.N.SG.ACC give.3.SG 'To Kostas, who will give it to him?'

c. Tu Kósta o IIÓRkos na tu to the Kosta.DAT the GEORge.NOM SUBJV 3.M.SG.DAT 3.N.SG.ACC ðóki. give.3.SG 'To Kostas, it is GEORge that should give it to him.'

d. Tu Kósta o IIÓRkos énna tu to the Kosta.DAT the GEORge.NOM FUT 3.M.SG.DAT 3.N.SG.ACC Jóki.

give.3.SG

'To Kostas, it is GEORge that will give it to him.'

The partial order in the CG preverbal field is, thus, as follows:

(27) TopP WhP/FocusP Mod/Neg CL v 
(27), in combination with the data presented in section 3.1, leads to the following descriptive generalization (to be further revised):

Generalization 1:

(28) Merger of a constituent ( $\mathrm{X}$ or XP) above the $C, V$ cluster and up to TopP triggers proclisis.

In other words, in CG the proclisis-enclisis alternation appears to correlate with the structural cut-off point between old and new information. In the following section the position of complementizers is discussed.

\subsubsection{Complementizers}

As it has been pointed out earlier, complementizers in CG may trigger proclisis (29a), although some trigger both proclisis and enclisis (29b), while some trigger only enclisis (29c) (see Agouraki 2001; Chatzikyriakidis 2010; 2012; Revithiadou 2006, 2007):

(29) a. Lipúme pu tin iðes /*iðes tin be.sorry.1.SG that 3.F.SG.ACC see.PST.2.SG/*'see.PST.2.SG 3.F.SG.ACC étsi.

thus

'I am sorry that you saw her like this.'

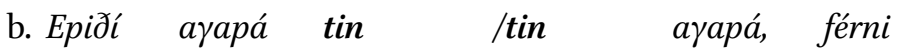
because love.3.SG 3.F.SG.ACC /3.F.SG.ACC love.3.SG bring.3.SG tis lulúvkia.

3.F.SG.DAT flowers.ACC

'Because he loves her, he brings her flowers.'

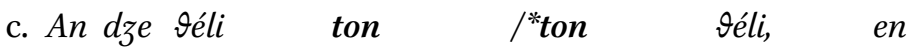
if and want.3.SG 3.M.SG.ACC $/{ }^{*} 3 . M . S$ G.ACC want.3.SG NEG tu to léi.

3.M.SG.DAT 3.N.SG.ACC say.3.SG

'Although she wants him, she does not let him know.'

Starting from the non-optional cases in (a) and (c) above, the issue here is that two distinct complementizers, presumably merged in the same structural position (i.e. c), trigger either proclisis (a) or enclisis (c). This may suggest that the position of the clitic before or after the verb is not related to the structural posi- 
tion of the complementizer, clearly a counter-intuitive conclusion. Fortunately, it has been shown that some embedded/dependent clauses exhibit more rootlike properties as opposed to others (see, e.g., Emonds 2004; Iatridou \& Kroch 1992), a difference plausibly linked to the higher vs. lower position of the complementizer introducing the embedded clause in each case. In other words, not all complementizers seem to be merged in the same structural position. This conclusion has been independently reached by the cartographic approach on the basis of various empirical phenomena, including recomplementation phenomena in languages that allow them (e.g. Spanish, European Portuguese, Italian or English varieties), but also with respect to cases where preverbal topics or foci may precede a (low) complementizer. In this respect, consider the following sentences from SG (examples adapted from Roussou 2000):

\section{(30) a. Ípan ton Níko pos ton iðe i said.3.PL the Nick.ACC that 3.M.SG.ACC see.PST.3.SG the María. \\ Maria.NOM}

b. Ípan pos ton Niko ton íđe i María. 'They said that as far as Nick is concerned, Mary saw him.'

$\begin{array}{llllll}\text { c. } M e \quad \text { rótisan ton JÁNI } & \text { an } \vartheta e ́ l o ~ n a ~ & \text { to } \\ \text { 1.SG.DAT asked.3.PL the JOHN.ACC } & \text { if } & \text { want.1.SG } & \text { SUBJV } & \text { see.1.SG }\end{array}$

d. Me rótisan an Өélo ton JÁNI na ðo.

e. Me rótisan an Өélo na ðo ton JÁNI.

'They asked me if it was John that I wanted to see.'

These sentences illustrate the fact that in SG a preverbal object topic or focus may precede or follow certain complementizers (here pos, an, and $n a$ ). It has been argued (see Roussou 2000) that when a preverbal focus or topic phrase precedes the complementizer (cf. 3 oa \& 3oc-d), the latter is merged low (i.e. close to what Rizzi 1997 dubs CFin). The opposite would hold for those cases where the focus or topic phrase follows the complementizer (3ob \& 3oe). On the basis of this background, we could further hypothesize that in (29a) the complementizer $p u$ is merged low and triggers proclisis (presumably because a low comp blocks v-movement across the cliticization site), whereas in (29c) the complementizer an dze is merged high and triggers enclisis. According to this hypothesis, variation in the structural position of the complementizer directly 
correlates with variation in the structural position of the clitic (and therefore with proclisis-enclisis). This would be a welcome result, as in the previous section we saw that the structural position of preverbal XPs, and Xs other than complementizers (e.g. the negation head) does correlate with the proclisisenclisis alternation. So, what is the evidence for this hypothesis?

Although there is much we do not know about the left periphery of CG clauses, we may assume that $\mathrm{CG}$ and $\mathrm{SG}$ are similar in this respect. Starting from cases of obligatory enclisis $(29 \mathrm{c})$, what is interesting about the complementizer an dze is that it is composed of two independently existing homophonous morphemes, namely the complementizer an ('if') and the conjunction $d_{z}$ ('and'). Whereas an typically correlates with proclisis, $d z e$ always triggers enclisis. On the other hand, an dze (on its own) triggers enclisis (and the same applies to other complex complementizers containing dze; see also Agouraki 20o1; Chatzikyriakidis 2012). Why should this be the case? Assuming that an dze is a conjunction-like element might provide an answer to this question, as bona fide conjunctions are associated with enclisis when they conjoin clauses (31):

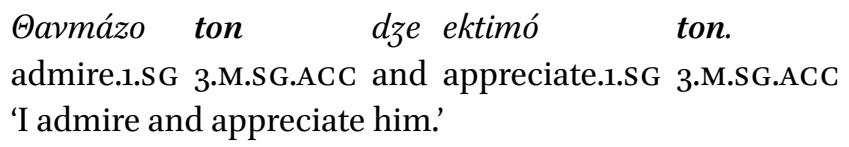

The standard intuition is that the conjunction in (31) does not count as being part of the second clause (and see Schütze 2004 and references therein for second position cliticization). However, there are reasons to believe that an $d_{3}$ in $(29 \mathrm{c})$ is a complementizer, and not a conjunction. For example, $(29 \mathrm{c})$ is rendered ungrammatical if one deletes an dze or an, but not if one deletes dze. Moreover, dze on its own may assume a complementizer-like use, in which case it triggers enclisis and cannot be deleted (while keeping the reading constant):
(32) a. Píe
dze éðokèn
tis
to.
go.PST.3.SG and give.PST.3.SG 3.F.SG.DAT 3.N.SG.ACC 'S/he went and gave it to her.'
b. Akúi tin dze lalí tu óti... listen.3.SG 3.F.SG.ACC and tell.3.SG 3.M.SG.DAT that 'He hears her telling him that ...'

If an dze is a high complementizer (what Rizzi 1997 calls 'a subordinator' or CForce), one prediction is that it should precede preverbal topics and/or foci as well as preverbal particles such as negation. This prediction is borne out, as 
illustrated by the following examples (and similar facts would apply to other complementizers containing $d z$, although this is not shown here due to lack of space):

(33) a. An dze ton Tiórkon Yéli ton ...11 if and the George.ACC want.3.sG 3.M.SG.ACC 'Although she wants George ...'

b. An dze o Tiórkos KÁtI tis if and the George.Nom SOMETHING.ACC 3.F.SG.DAT éðoke ... give.PST.3.SG 'Although George gave her Something ...'

c. An dze en to véli... if and NEG 3.N.SG.ACC want.3.SG 'Although s/he does not want it ...'

Given the high comp status of an dze and the fact that it always triggers enclisis, we may assume that its high structural position is causally linked to clitic positioning.

To see if this is indeed the case, let us move on to (29a), which involves a factive $p u$, repeated here for convenience:

11 Note that a topic phrase preceding an dze is ungrammatical, unless it is construed as a main clause topic (in which case it cannot belong to the clause introduced by an $d z e$ ):

(i) An dze ton Fiórkon en ton véli, eyó en tis

If and the George.ACC NEG 3.M.SG.ACC want.3.SG, I.NOM NEG 3.F.SG.DAT miláo.

speak.1.SG

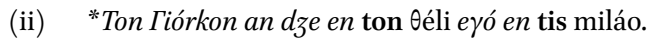

(iii) Tis Marías, an dze ton Fiórkon en ton véli, eyó The Maria.DAT if and the George.ACC NEG 3.M.SG.ACC want.3.SG I.NOM en tis miláo.

NEG 3.F.SG.DAT speak.1.SG

'Although Maria does not want George, I do not speak to her.' 

(34) Lipúme pu tin ¡ðes /*iðes tin be.sorry.1.SG that 3.F.SG.ACC see.PST.2.SG/*'see.PST.2.SG 3.F.SG.ACC étsi.
thus

'I am sorry that you saw her like this.'

This is an example of a complementizer which (on its own) triggers obligatory proclisis. ${ }^{12}$ This should follow from its low (<TopP) structural position. An immediate problem for this hypothesis is that $p u$ obligatorily precedes preverbal topics:

(35) a. Lipúme pu tu Kósta en tu emílises. be.sorry.1.SG that the Kosta.DAT NEG 3.M.SG.DAT speak.PST.2.SG 'I am sorry that to Kostas (that) you did not speak to him.'

b. ?*'Lipúme tu Kósta pu en tu emílises.

One could assume that $p u$ in (35a) checks some feature below TopP before moving on to some pre-topic position, and that its copy is sufficient to trigger proclisis. However, this would predict that we should get proclisis independently of the nature of the constituents preceding the clitic cluster, contrary to fact:

(36) Lipúme pu tu Kósta $(p u)$ emilisès tu be.sorry.1.SG that the Kosta.DAT (that) speak.PST.2.SG 3.M.SG.DAT /*tu emílises.

/*3.M.SG.DAT speak.PST.2.SG

'I am sorry that to Kostas (that) you talked to him.'

(36) shows that a preverbal object topic triggers enclisis in the presence of $p u$. If $p u$ had originated below tu Kósta (cf. the copy of $p u$ ), and if a copy were a sufficient condition to trigger proclisis, we would expect proclisis to be possible, contrary to fact. This suggests that the spell-out position of $p u$ is the crucial factor. Moreover, it suggests that proclisis in (35a) is due to the presence of negation rather than to the presence of (a copy of) $p u$. The immediate question

12 Other complementizers of the same type include relative $p u$ ('that'), interrogative and conditional an ('if'), as well as complementizers introducing temporal adjunct clauses (e.g. ama ('when'), pu ('when'), or prin ('before')). 
that arises is how to account for simple cases like (34), and like (37) below: if $p u$ is merged/spelled out high, then how is it possible that it triggers proclisis?

(37) Lipúme pu tu emílises.

be.sorry.1.SG that 3.M.SG.DAT speak.PST.2.SG

'I am sorry that you spoke to him.'

There are at least two plausible ways to deal with this issue. One alternative would be to assume that $p u$ is always merged/spelled-out high, but whether enclisis or proclisis obtains depends on whether $p u$ is contained or not within the same prosodic domain as the clitic (cf. that CG clitics cannot appear at the edge of some prosodic domain). If the presence of a preverbal topic blocks this particular prosodic phrasing (a straightforward assumption, given what we know about the prosody of preverbal topics), it would explain why enclisis obtains in (36) (there is no host for the clitic within the prosodic domain containing it), as well as why proclisis obtains in (35a) (the negation particle and the clitic are merged/spelled-out within the same prosodic domain, independently of $p u$ ). A second alternative would be to claim that $p u$ always merges low, triggering proclisis. Any difference would follow from the amount of structure $p u$ merges with in each case: whereas in (37) pu merges with a clausal chunk that only contains $\{\mathrm{Cl}, \mathrm{v}\}$ (presumably, a TP/INFLP, given standard assumptions on cliticization, and see also section 4), in (35) and (36) it merges with a bigger clausal chunk (namely, one that contains $\{$ Top, $\mathrm{Cl}, \mathrm{v}\}$ (presumably, a TopP)). Assuming this is correct, a complementizer like $p u$, which triggers proclisis when on its own, would be free to merge with clausal chunks of variable sizes (including a TP/INFLP). On the other hand, a (high) complementizer like an dze, which triggers enclisis when on its own, would be free to merge with any constituent besides TP/INFLP.

Why this would be the case is far from clear. What strikes me as important is that both alternatives propose more or less the same thing, but also face a similar problem. In particular, both argue that a proclisis trigger (which includes complementizers like $p u$ ) needs to form a contiguous domain with the clitic (cluster), although the nature of this domain differs depending on the alternative (syntactic vs. prosodic). In any other case, enclisis obtains. The problem that both seem to be facing is that whereas $p u$ is able to count as part of the prosodic or clausal chunk that contains inflectional information (including the clitic) (either via prosodic restructuring, or due to merger with TP/INFLP), this is not the case for an dze, which seems to be separated from it by some sort of barrier. This is an unavoidable conclusion, and it does correlate with clitic positioning. In addition, it is compatible with the intuition that whether 
some constituent counts as a proclisis trigger or not ultimately reduces to hierarchical structure (namely, its structural position), which was the essence of our working hypothesis (under the assumption that syntactic structure is directly related to prosodic structure). ${ }^{13}$ For all these reasons, I treat $p u$, and similar complementizers, as being able to merge below TopP.

That the structural position of a complementizer is crucial for clitic positioning becomes most clearly evident in the case of optional complementizers. An example of an optional complementizer was provided in ( $29 \mathrm{~b})$, which is repeated here for convenience:

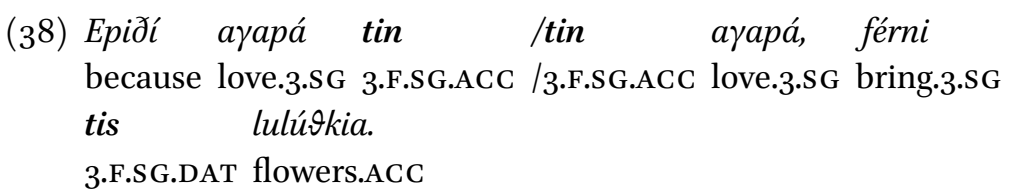

'Because he loves her, he brings her flowers.'

In CG, optional complementizers include among others óti and pos 'that', or epiðı and yiatí 'because' (see also Agouraki 20o1; Chatzikyriakidis 2012; Revithiadou 2006). Their common property is that they seem to be compatible with both proclisis and enclisis. One way to capture these facts is by postulating that optional complementizers may be either low or high: a low complementizer (or, given the discussion in the previous paragraph, a complementizer that may merge with TP/INFLP) triggers proclisis, as opposed to a high complementizer (or, alternatively, a complementizer that cannot merge with TP/INFLP), which triggers enclisis. This hypothesis is consistent with the overall empirical picture, given that low—only complementizers trigger proclisis, as opposed to high — only ones, which trigger enclisis.

One piece of evidence in favour of this analysis is the fact that high vs. low complementizers also correlate with semantic/pragmatic differences (besides prosodic/phonological differences). This suggests that they involve distinct morpho-syntactic features (a fact that increases the chances they are merged in distinct positions).${ }^{14}$ Consider the following pair of sentences from Asturian, a language that behaves like CG as far as finite enclisis is concerned:

13 This conclusion would be further supported, if at least some of the complementizers that trigger proclisis could be shown to allow preverbal constituents, including topics and foci. This is an issue for further research.

14 In this respect, see Pesetsky \& Torrego (2001), who propose a double C analysis for Spanish embedded questions (on the basis of featural content), which among other things 
(39) a. Digo qu' ayúda=me [\#pero nun toi seguru]. say.1.SG that help.3.SG=1.SG [\#but not am sure] 'I say that s/he helps me, \#but I am not sure (that s/he does help me).' [Asturian; Fernández-Rubiera 2013: 79 (his (50))]

b. Digo que me ayuda [pero nun toi seguru]. say.1.SG that 1.SG help.3.sG [but not am sure] 'I say that s/he helps me, but I am not sure (that s/he does help me).' [Asturian; Fernández-Rubiera 2013: 79 (his (50))]

According to Fernández-Rubiera, enclisis in (39a) correlates with a high Comp (which does not block V-movement to CFin), which in turn correlates with epistemic modality (i.e. the speaker asserts that the reported content is true) and enclisis. (39b), on the other hand, correlates with a low Comp (which blocks v-movement to CFin), which in turn also correlates with epistemic modality (in this case the speaker does not assert the truthfulness of the reported content) and with proclisis. Similar semantico-pragmatic effects have been reported for embedded v2 in Germanic languages (see, e.g., Meinunger 2006; Truckenbrodt 2006), and they have been linked to the root vs. non-root distinction. More importantly, they seem to hold also in CG. In this respect, consider the following sentences: ${ }^{15}$

(40) a. Léro óti evoî́isèn me [\#ma en íme síyuros]. say.1.SG that help.PST.3.SG 1.SG.ACC [\#but not am sure]

b. Léro óti me evoîisen [ma en íme síyuros]. say.1.SG that 1.SG.ACC help.PST.3.SG [but not am sure] 'I say that s/he helped me (\#) but I am not sure.' [CG]

The effect is identical with Asturian: the óti Comp that allows for enclisis correlates with assertion of the truthfulness of the reported content by the speaker, as opposed to the óti Comp that allows for proclisis (where the content is only reported but not asserted). This fact, which has not been previously reported for CG, clearly suggests that the two complementizers differ in seman-

accounts for the lack of that-trace effects. Interestingly enough, both CG and SG have H (see section 4.3), lack that-trace effects, and have obligatory v-to-T movement. Thanks to an anonymous reviewer for pointing out this link to me.

15 Thanks to Christina Giannapi for these judgments. 
tic terms, and by default (given our current understanding of grammatical models) also in syntactic terms (including features and possibly positioning, or alternatively the portion of structure projected above the CL V cluster). This analysis is supported by independent prosodic evidence: whereas in (40a) óti

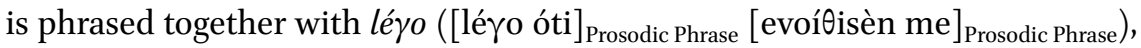

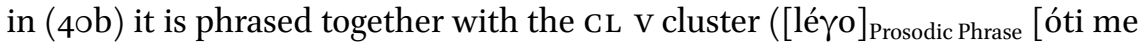
evoílisen $]_{\text {Prosodic Phrase }}$ ) (for prosodic phrasing in CG óti clauses see Revithiadou 2006). This fact comes for free, if (40a) and (4ob) have distinct syntactic structures.

Where does this discussion leave us regarding CG? It seems that preliminary investigation strongly suggests that complementizers for which we have independent evidence that they are merged low in the clause (i.e. below TopP but higher than TP/INFLP) trigger proclisis, while complementizers for which we have evidence that they are merged higher in the clause (i.e. above TopP) trigger enclisis. This gives us the following (revised) empirical generalization:

Generalization 1':

(41) Merger of a constituent (X or XP) above the CL V cluster and up to TopP triggers proclisis. This also includes complementizers merging at some position lower than TopP

If a low Comp may be merged either above or below a FocusP/WhP (but lower than TopP; see also Roussou 2000), one gets the following structure (where one may assume, for expository reasons, that $\mathrm{XP}=\mathrm{TP} / \mathrm{INFLP} ; \mathrm{C}_{3}=$ CForce; $\mathrm{C}_{1}=\mathrm{CFin}$ and TopP = Left Dislocated Topic/LD):

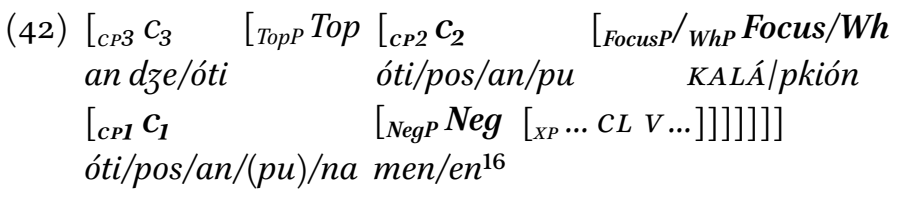

In this case, v-merger to a head higher than the cliticization site is blocked $\left({ }^{*} \mathrm{v}\right)$, and proclis obtains:

16 It is not clear to me where énna would be in this structure. One possibility that comes to mind is $\mathrm{C}_{1}$ (the position of $n a$ ), as it is an invariable particle realizing modal inflection. For a discussion of CG énna, see Christodoulou \& Wiltschko (2012), Merchant \& Pavlou (this volume). 


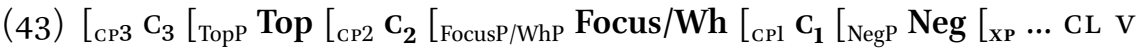
... []]]]]]]

On the other hand, if no head or spec within that area is realized/merged, then (finite) enclisis obtains through merger of $\mathrm{v}$ across the cliticization site $(\mathcal{} \mathrm{V})$ :

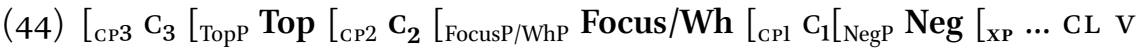
...][]]]]]

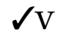

This give rise to the following abstract generalization:

Generalization 1":

(45) Realization of a spec or a head within a particular area within the high TPlow CP domain blocks realization of the verb within that same domain.

What is the best way to analyse this distribution? For example, does the complementary distribution pattern involve the spec and head of a single syntactic head? Why are only heads within a particular domain subject to this pattern? How can we capture the fact that distinct morpho-syntactic heads are subject to the same pattern? Finally, why should the spell-out position of an XP interact with the realization of the verb (i.e. of a head)? These issues are taken up in the following section.

\section{EPP as a PF edge requirement}

Let us repeat the generalization formulated in section 3.2.2 above. What the data show is that finite enclisis in CG involves activation of the high TPlow CP domain, in the following manner: when a head or phrase is merged and/or spelled out within this domain, proclisis obtains. Otherwise, we get enclisis. In other words, any single feature merged and/or spelled out within this particular domain is sufficient to trigger proclisis, independently of its precise position within that domain. If we assume that enclisis involves the realization of (a copy of) the verb in some position higher than the cliticization site, then it is simpler to assume that the complementary distribution pattern observed with finite enclisis derives from some restriction applied to a single projection. Given that phonological realization is conditioned by the presence 
of a morpho-syntactic copy, it follows that the restriction must be PF in nature (see also Landau 2007 for a detailed discussion, and also the analysis below), as syntax does not prevent the presence of both copies at the same projection (although it does not force it, either). This is the claim I am going to make in this section. Before I move on to the analysis, let me first present my assumptions.

\subsection{Assumptions}

I make the following four assumptions regarding cliticization and the creation of verbal copies within the clausal extended functional projection.

\subsubsection{Assumption 1: clitics}

Clitics in CG (and SG) target the periphery of vP (to check case and/or a Topic feature), and the periphery of TP/INFLP (to check deixis and/or person; see e.g. Anagnostopoulou 2003; Mavrogiorgos 2010; Terzi 1999a,b):

(46) $\left[{ }_{\mathrm{CP}} \mathbf{C}\left[{ }_{\mathrm{TP}} \mathbf{C L}\left[{ }_{\mathrm{TP}} \mathrm{T}\left[{ }_{\mathrm{vP}}(\mathbf{C L})\left[{ }_{\mathrm{vP}} \mathbf{V}(\mathbf{C L})\right]\right]\right]\right]\right]$

4.1.2 Assumption 2: c-selection of functional heads

A functional head locally c-selects (the head of) its complement (potentially via AGREE or FEATURE SHARE, given available feature matrices in Lexicon List 1). This gives rise to one or more morpho-syntactic dependencies/chains (cf. (47) for a standard case; see also Landau 2006, 2007; Pesetsky \& Torrego 2001; Zwart 2001), where a chain may be phonologically realized by one or more items (this depends on morphological factors, as e.g. the available vocabulary items (see, e.g., Embick 2000), or on the morphological/affixal properties of the head of the chain and/or its position at a prosodic edge-see Lasnik 1995; Platzack 2010; Richards 2016; Zwart 2001, and section 4.3 below).

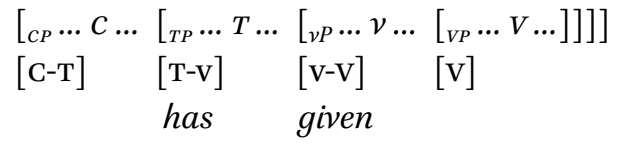

4.1.3 Assumption 3: head movement

Head movement is contingent on AGREE among heads. While nothing precludes the creation of a higher copy via internal merger (in which case we would expect to get interpretative effects-see Lechner 2007; Roberts 2010), I assume that in the default case the actual movement part is delegated by PF (e.g. through an 'affixal/morphological' requirement on a c-selecting headsee Landau 2006 on Hebrew V(P) - fronting). As discussed later on in section 4.3, this assumption is empirically supported by non-finite enclisis. 


\subsection{4}

Assumption 4: content is separate from function and structural position

The final assumption is the most important but at the same time the most controversial one. In particular, the first head $\mathrm{H} \mathrm{c}$-selecting тP may come in flavours, in that it hosts some (interpretable) morpho-syntactic feature $f$ compatible with this particular domain (e.g. a modal feature, a negation/affirmation feature, or an operator feature):

(48) a. $\left[\cdots\left[{ }_{\mathrm{HP}} \mathbf{H}_{[+\mathrm{f}]}\left[\mathrm{TP}_{\mathrm{TP}} \mathrm{T}[\mathrm{vP} \cdots \mathrm{v} \ldots]\right]\right]\right]$

b. $\mathbf{H}=\left\{\mathrm{f}_{1} ; \mathrm{f}_{2} ; \ldots \mathrm{f}_{\mathrm{n}}\right\}$ and feature projection is subject to $\mathrm{f}_{1}>\mathrm{f}_{2}>\ldots \mathrm{f}_{\mathrm{n}}$

Only a single feature at a time may be inserted in $\mathrm{H}$ (modulo the c-selection feature, which is not interpretable, as opposed to $f$ ). Feature insertion is regulated by a feature insertion algorithm of some sort (see 48b), which, hopefully, could be reduced to independent semantic-syntactic properties. Crucial for our analysis is the fact that not any feature can be inserted in H: topic features (or any other 'higher' feature ('higher' in the sense of Rizzi 1997) that does not belong to the core of the clause) cannot appear in $\mathrm{H}$. Despite featural variation, the structural position of $\mathrm{H}$ remains constant. The same applies to its function, which is that of marking the edge of a morpho-syntactic domain prosodically and semantico-pragmatically (cf. that $\mathrm{H}$ carries interpretable features realized by stress or an overt lexical item, and constitutes the cut-off point for the theme-rheme division). The dissociation of content from function and structural position (see Ritter \& Wiltschko 20o9) allows us to take into account the variation we have seen, which cannot be accounted for on the basis of a single morpho-syntactic property (e.g. the relevant features do not form a natural class), and at the same time to account for the predictable interaction between $\mathrm{H}$ (a prominent structural position) and finite enclisis. Moreover, and as discussed in section 4.3 , it opens the way for a principled account of crosslinguistic variation with respect to finite enclisis.

\subsection{Analysis}

Having presented my assumptions, I wish to make the following theoretical claim, on the basis of the empirical model presented in section 3 :

\section{2 .1}

Theoretical claim

(49) H has a (morpho-)syntactic requirement and an Edge Requirement, which are separate though interdependent. 
The (morpho-)syntactic requirement of $\mathrm{H}$ reduces to the presence of an unvalued morpho-syntactic feature $f$ (inserted in H via 48), which AG REEs with a matching $\mathrm{XP} / \mathrm{X}$ and leads to the creation of a copy at $\mathrm{H}$ (with subsequent interpretational and $\mathrm{PF}$ realization effects). Since not any feature may be inserted in $\mathrm{H}$, this captures why not any XP or X may participate in the complementary distribution pattern discussed in section 3 .

The Edge Requirement ensures that (the valued feature in) $\mathrm{H}$ be realized by (the overt copy of) an X or XP merged at $\mathrm{H}$ (see also Collins 2007; Landau 2007; Nchare \& Terzi 2014), where H extends TP (see Roberts 2010 for X and XP being able to extend the root):

(50) $\left.\left[\ldots\left[{ }_{\mathrm{HP}} \operatorname{Spec}\left[{ }_{\mathrm{H}^{\prime}} \mathbf{H} \ldots{ }_{{ }_{\mathrm{TP}} \mathrm{T}} \mathrm{T}\left[{ }_{\mathrm{vP}} \mathrm{V}\left[{ }_{\mathrm{vP}} \mathrm{V}\right]\right]\right]\right]\right]\right]$

The Edge Requirement is a PF requirement: (a) it marks the edge of тP (via phonological realization), possibly for linguistic (e.g. prosodic) and/or extralinguistic (e.g. processing) factors, and with pragmatico-semantic correlates (cf. the theme-rheme division); ${ }^{17}$ (b) it is satisfied locally (i.e. by a copy at $\mathrm{H}$ ) and once (only the spec or the head of HP may be realized); (c) if HP cannot be realized overtly, PF spells-out the copy of $\mathrm{T}$ on $\mathrm{H}$ (via c-selection) as a last resort. If the phonological exponent realizing $\mathrm{H}$ is affixal, obligatory head movement ensues (no complementary distribution pattern; see next section). ${ }^{18}$

Let us now see how the Edge Requirement derives the finite enclisis patterns in CG (irrelevant details are omitted):

\subsubsection{1 (Preverbal) wh-phrase: proclisis}

An unvalued [wh] feature is inserted in $\mathrm{H}$ and AGREEs with the wh-phrase. The latter is merged in spec HP (possibly for independent PF reasons; see Richards 2016), and spelled-out at $\mathrm{H}$ (in which case the Edge Requirement is trivially satisfied, $\mathrm{T}$ is spelled out in situ, and proclisis obtains):

\footnotetext{
17 For similar ideas from V2, see Mohr (2009); Zwart 2005.

18 An anonymous reviewer asks how the analysis proposed here differs from the prosodic account offered by Revithiadou $(2006,2007)$. Although both analyses assume that PF has a filtering role only, according to Revithiadou any differences between proclisis and enclisis triggers is related solely to their distinct prosodic properties (contrary to the analysis defended in this paper). That an identical syntax-distinct prosody account does not work is made evident by both optional complementisers (see section 3.2.2) and by Dlinked wh-phrases (see sections 3.1 and 3.2.1) (the very same empirical phenomena used by Revithiadou herself), which have distinct syntactico-semantic properties that naturally map onto distinct prosodic structures.
} 


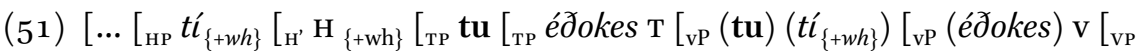
(tu) (éðokes) $\left.\left.\left.\left.\left.\left.\left.\left.\mathrm{v}\left(t i_{\{+ \text {wh }\}}\right)\right]\right]\right]\right]\right]\right]\right]\right]$

4.2.1.2 Na-particle \& negation particle: proclisis

An unvalued [modal] or [negation] feature is inserted in $\mathrm{H}$. $\mathrm{Na}$ (in the case of a modal morpheme) or en/min (in the case of a negation morpheme) externally merge at $\mathrm{H}$, checking the relevant feature. Local spell-out satisfies the Edge Requirement, $\mathrm{T}$ is spelled out in situ, and proclisis obtains:

(52) $\left[\ldots\left[_{\mathrm{HP}}\left[_{\mathrm{H}^{\prime}} n a_{\{+m o d\}} \mathrm{H}_{\{+\bmod \}}\left[_{\mathrm{TP}} \mathbf{t u}\left[_{\mathrm{TP}}\right.\right.\right.\right.\right.$ ðókis T $\left[_{\mathrm{vP}}(\mathrm{tu})\left[_{\mathrm{vP}}\left(\right.\right.\right.$ ðókis) $\mathrm{v}\left[_{\mathrm{vP}}(\mathrm{tu})\right.$ (ðókis) v míla]]]]]]]]

(53) $\left[\ldots\left[_{\mathrm{HP}}\left[{ }_{\mathrm{H}^{\prime}} e n_{\{+n e g\}} \mathrm{H}_{\{+ \text {neg\} }}\left[_{\mathrm{TP}} \mathbf{t u}\left[_{\mathrm{TP}}\right.\right.\right.\right.\right.$ édokes $\mathrm{T}\left[_{\mathrm{vP}}(\mathbf{t u})\left[_{\mathrm{vP}}(e ́ d o k e s) \mathrm{v}\left[{ }_{\mathrm{vP}}(\mathbf{t u})\right.\right.\right.$ (éðokes) v míla]]]]]]]] ${ }^{19}$

\subsubsection{3 (Low) complementizer: proclisis}

An interpretable though unvalued [comp] feature (cf. interpretational effects of low vs. high comps) is inserted in $\mathrm{H}$, and checked by external merger of a (low) matching complementizer, which satisfies the Edge Requirement and triggers proclisis:

(54) $\left[\cdots\left[_{\mathrm{HP}}\left[{ }_{\mathrm{H}^{\prime}}\right.\right.\right.$ óti $i_{\{+c o m p\}} \mathrm{H}_{\{+ \text {comp }\}}\left[_{\mathrm{TP}} \mathbf{t u}\left[_{\mathrm{TP}}\right.\right.$ éðokes T $\left[_{\mathrm{vP}}(\mathbf{t u})\left[_{\mathrm{vP}}(\right.\right.$ éðokes $) \mathrm{v}\left[_{\mathrm{vP}}(\mathbf{t u})\right.$ (éðokes) v míla]]]]]]]]

All the above cases involve an X or XP spelled-out at $\mathrm{H}$. If nothing gets merged and/or spelled-out at $\mathrm{H}$, enclisis obtains. This is illustrated below with Left Dislocated topics and verb-initial sentences.

\subsubsection{Clitic left dislocated topics: enclisis}

As illustrated in (55) below, a Clitic Left Dislocated topic is merged in a position higher than $\mathrm{H}$, presumably due to the fact that [top] cannot be inserted in $\mathrm{H}$ (this empirical fact is not well understood but seems to hold across many languages):

19 In the case of $\mathrm{min}$, which is obligatorily selected by $n a$, the simplest hypothesis would be to assume that it is generated in a separate modal head c-selecting $\mathrm{H}_{\{\text {neg }}$. Thanks to the editor for pointing out this issue to me. 
(55) a. Ta míla pulís mas ta?

the apples.ACC send.2.SG 1.PL.DAT 3.N.PL.ACC

'The apples, do you sell them to us?'

b. $\left[\ldots\left[_{\text {TopP }}\right.\right.$ Ta míla $a_{\{+t o p\}}\left[_{\text {Top' }} \operatorname{Top}_{\{+ \text {top }\}}\left[_{\mathrm{HP}}\left[{ }_{\mathrm{H}^{\prime}} \mathrm{H}_{\{+\mathrm{T}\}}\left[_{\mathrm{TP}}\right.\right.\right.\right.$ mas ta $\left[_{\mathrm{TP}}\right.$ pulís $\mathrm{T}\left[_{\mathrm{vP}}\right.$ (ta míla $\{+\mathrm{top}\})($ mas $)\left(\right.$ ta) $\left[_{\mathrm{vP}}\right.$ (pulís) $\mathrm{v}\left[_{\mathrm{vP}}\right.$ (mas) (ta) (pulís) $\mathrm{v}$ (ta míla $\{$ top\} $)]][]]]]]]]$

In 55 (b), no X or XP is merged at $\mathrm{H}$. At some later point, 55 (b) is shipped off to $\mathrm{PF}$. H contains only a $\{\mathrm{T}\} / \mathrm{c}$-selecting feature, which has been valued via merger with TP. Assuming that the $\{\mathrm{T}\}$ feature constitutes a copy of $\mathrm{T}$ in $\mathrm{H}, \mathrm{PF}$ choses to spell out this copy, which satisfies the Edge Requirement as a Last Resort and gives rise to enclisis (see Landau 2006 for Hebrew; see also Raposo \& Uriagereka 2005 for the same intuition for Western Iberian):

PF structure:

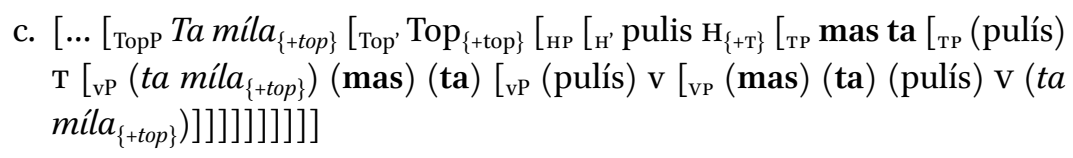

\subsubsection{V-initial cases: enclisis}

A Last Resort analysis also applies to V-initial cases, as shown in (56) below (note that the enclisis-proclisis alternation does not correlate with the interrogative vs. declarative distinction, which either implies that [interr] or [decl] are merged in some head higher than $\mathrm{H}$, or that they are in $\mathrm{H}$ but their licensing is unrelated to the spell-out position of $\mathrm{T}$ ):

(56) a. Pulís mas ta mila?/.

sell.2.SG 1.PL.DAT the apples.ACC

'Do you sell us the apples?/You sell us the apples.'

b. $\left[\cdots\left[_{\mathrm{HP}}\left[{ }_{\mathrm{H}^{\prime}} \mathrm{H}_{\{+\mathrm{T}\}}\left[_{\mathrm{TP}}\right.\right.\right.\right.$ mas $\left[_{\mathrm{TP}}\right.$ pulís $\mathrm{T}\left[_{\mathrm{vP}}(\right.$ mas $)\left[_{\mathrm{vP}}(\right.$ pulís $) \mathrm{v}\left[{ }_{\mathrm{vP}}(\right.$ mas $)$ (pulís) ta míla]]]]]]]]

PF structure:

c. $\left[\ldots\left[_{\mathrm{HP}}\left[_{\mathrm{H}^{\prime}}\right.\right.\right.$ pulís $\mathrm{H}_{\{+\mathrm{T}\}}\left[_{\mathrm{TP}}\right.$ mas $\left[_{\mathrm{TP}}\right.$ (pulís $) \mathrm{T}\left[_{\mathrm{vP}}(\right.$ mas $)\left[_{\mathrm{vP}}(\right.$ pulís $) \mathrm{v}\left[_{\mathrm{VP}}(\right.$ mas $)$ (pulís) ta míla]]]]]]]] 
When more than one constituents are merged preverbally, it is the closest one to тP that triggers enclisis/proclisis. Below I provide one derivation with proclisis and one with enclisis:

\subsubsection{Preverbal neg particle and a cLLDed object topic: proclisis}
a. Ta míla
en mas ta
éðoke.

the apples.ACC NEG 1.PL.DAT 3.N.PL.ACC give.PST.3.SG

'The apples he did not give them to us.'

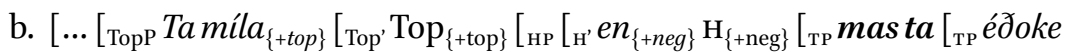

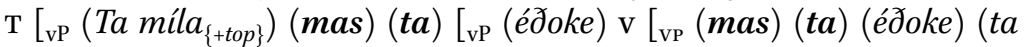
míla $\left.\left.\left.\left.\left.\left.\left.\left.\left.\left.\left._{\{+ \text {top\}}}\right)\right]\right]\right]\right]\right]\right]\right]\right]\right]\right]$

Here, [neg] is merged in $\mathrm{H}$ and checked by the negation particle, triggering proclisis. [Top] is merged higher up, and does not affect clitic positioning.

\subsubsection{Preverbal comp and CLLDed object topic: enclisis}
a. Ípen mu pos tu Kósta édokè tu say.PST.3.SG 1.SG.DAT that the Kosta.DAT give.PST.3.SG 3.M.SG.DAT to vivlío $i$ María. the book.ACC the Maria.NOM
'He told me that as far as Kostas is concerned, Mary gave him the book.'

In (58), pos may either merge in $\mathrm{H}$ (provided that $\mathrm{H}$ has a [comp] feature), before it moves to a higher c-head (b), or it is directly merged in c ( $\left.b^{\prime}\right)$. In both cases, $\mathrm{H}$ fails to be spelled out, triggering the spell-out of $\mathrm{T}$ in $\mathrm{H}$ (which gives rise to enclisis $\left(\mathrm{c}\right.$ and $\left.\left.\mathrm{c}^{\prime}\right)\right)$ :

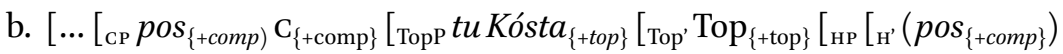

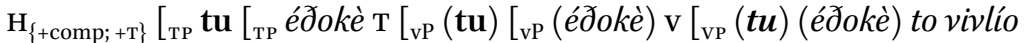
iMaría]]]]]]]]]]]

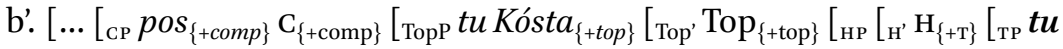

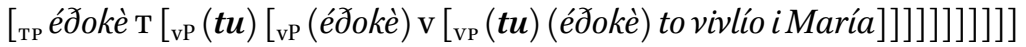


PF structure:

c. $\left[\cdots\left[_{\mathrm{CP}} \operatorname{pos}_{\{+c o m p\}} \mathrm{C}_{\{+\mathrm{comp}\}}\left[{ }_{\mathrm{TopP}} t\right.\right.\right.$ Kósta ${ }_{\{+t o p\}}\left[{ }_{\mathrm{Top}} \mathrm{Top}_{\{+\mathrm{top}\}}\left[\mathrm{HP}_{\mathrm{HP}}\left[\mathrm{H}_{\mathrm{H}}\left(\operatorname{pos}_{\{+c o m p\}}\right)\right.\right.\right.$

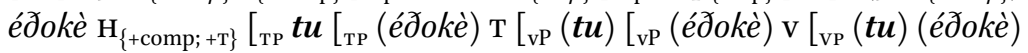
to vivlío i María ]]]]]]]]]]]]

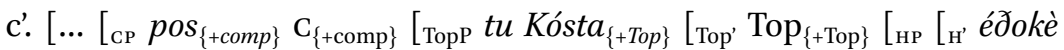
$\mathrm{H}_{\{+\mathrm{T}\}}\left[_{\mathrm{TP}} \boldsymbol{t u}\left[_{\mathrm{TP}}\left(\right.\right.\right.$ éðokè) $\mathrm{T}\left[{ }_{\mathrm{vP}}(\boldsymbol{t u})\left[_{\mathrm{vP}}\left(\right.\right.\right.$ éðokè) $\mathrm{v}\left[{ }_{\mathrm{vP}}(\boldsymbol{t u})\right.$ (éðokè) to vivlío $i$ María]]]]]]]]]]]

This completes the presentation of the main cases of finite enclisis in CG. The main claim presented was that $\mathrm{H}$ has an EPP requirement, which is decomposed into a morpho-syntactic and a $\mathrm{PF}$ requirement. The morpho-syntactic requirement involves AGREE between an unvalued feature inserted in $\mathrm{H}$ and a matching X or XP, which results in the creation of a copy. On the other hand, the $\mathrm{PF}$ requirement involves the Spell-Out of $\mathrm{H}$ by that copy, subject to the Economy Condition given in (7). It is the combination of the two requirements that gives rise to the finite enclisis patterns presented in section 3 .

\subsection{The nature of the $P F$ requirement and non-finite enclisis}

In this section, I discuss two additional issues: (a) non-finite enclisis in CG and SG and the role of affixal morphology in its obligatory nature (which indirectly supports the hypothesis that the Edge Requirement is a prosodic requirement-see also Franks 2015; Halpern 1995; Pancheva 2005; Schütze 2004 for prosodic edges vis-à-vis cliticization); (b) the lack of finite enclisis in $S G$ as a result of parameterization in the properties of $\mathrm{H}$.

As it was pointed out in section 2 above, CG (and SG) also has non-finite enclisis, found with imperatives and gerunds. The basic property of non-finite enclisis is that it is obligatory, contrary to finite enclisis. This is illustrated in (59) below, where the finite verb triggers proclisis only when preceded by the focused phrase (cf. 59 a vs. 59b), as opposed to the non-finite verb (cf. $59 \mathrm{c}-\mathrm{f}$ ):
a. ESÍ
to

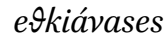
(i i Maria)?
YOU.NOM 3.N.SG.ACC read.PST.2.SG (or the Maria.NOM)
'Did you read it (or was it Mary)?'

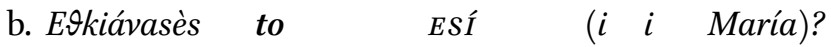 read.PST.2.SG 3.N.SG.ACC YOU.NOM (or the Maria.NOM) 'Did You read it (or was it Mary)?'




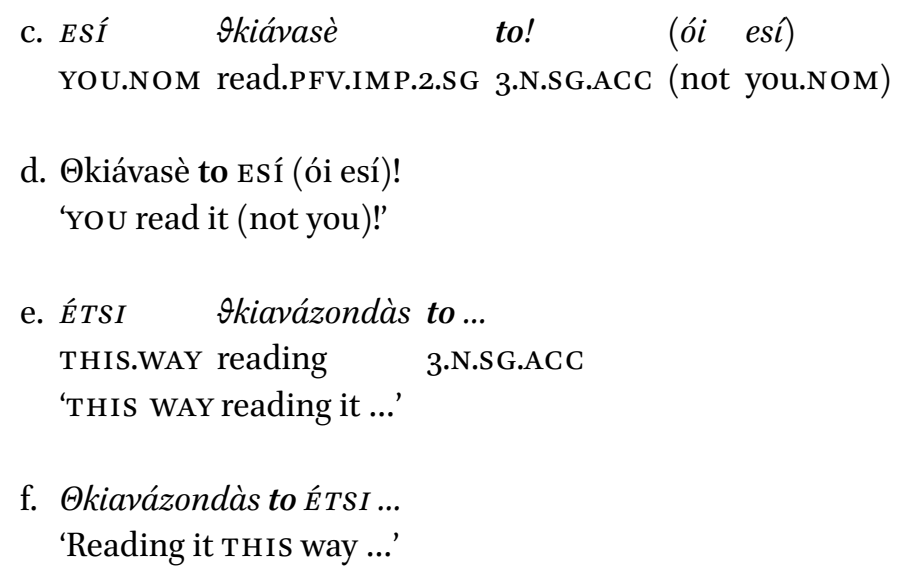

An analysis for non-finite enclisis along the lines of the analysis proposed for finite enclisis would fail: in (6o) H presumably has an unvalued [foc] feature, triggering focus movement to its spec, which should block spell-out of $\mathrm{T}$ in $\mathrm{H}$, contrary to fact.

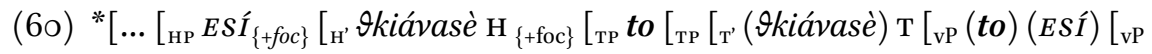

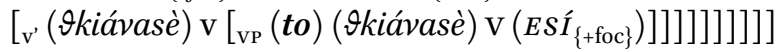

Given the special morphology of imperatives (and gerunds), and the fact that only one feature at a time may be inserted in $\mathrm{H}$, it seems more promising to link the obligatory character of non-finite enclisis to the morpho-syntactic properties of non-finite forms. In particular, it has been claimed in the literature (see Philippaki-Warburton 1992, 1998; Rivero \& Terzi 1995; Roussou 200o, and much subsequent literature) that non-finite verbal forms in SG must move out of TP due to their special morphology, which resides in C (as evidenced, e.g., by the fact that the presence of certain preverbal particles blocks their formation):

(61) a. $\left[n a / \vartheta a \quad\left[{ }_{T P} t u \quad\right.\right.$ Jinis $\quad$ /ðósis $\left.]\right]$ SUBJV/FUT 3.M.SG.DAT give.IPFV.2.SG/give.PFV.2.SG 'You should/will give him.'

b. ${ }^{*}\left[n a / \vartheta a \quad{ }_{T P} t u \quad\right.$ Jíne SUBJV/FUT 3.M.SG.DAT give.IPFV.IMP.2.SG /give.PFV.IMP.2.SG "*ive him!' 


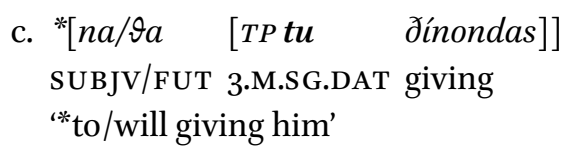

If $n a$ or $\vartheta a$ are merged in $\mathrm{H}$, and if they are in complementary distribution with imperative or gerund morphology, it makes sense to assume that the latter also resides in $\mathrm{H}$. If we further assume that this morphology is affixal (as opposed to $n a$ or $\vartheta a$, which aren't; see also Bošković 2004 for SG imperatives), this would account for the obligatory position of the non-finite verb form outside the TP, as well as for the fact that the Edge Requirement on $\mathrm{H}$ is satisfied trivially. As C G non-finite enclisis shares the same properties with SG enclisis, my suggestion is to extend this analysis to CG: $\mathrm{H}_{\{+\mathrm{imp} / \text { +ger\} }}$ (and only that, as $\mathrm{H}_{\text {\{interr/decl\} }}$ do not have special morphology and do not trigger obligatory enclisis), being affixal in nature, triggers obligatory spell-out of $\mathrm{T}$ in $\mathrm{H}$, satisfying the Edge Requirement trivially. Any other phrase (such as a focus phrase or a wh-phrase) would be merged in some higher head (given that $\mathrm{H}$ is already occupied). According to this analysis, the Edge Requirement is a prosodic requirement ( $\mathrm{H}$ marks the edge of $\mathrm{TP}$, presumably a prosodic domain), but this fact is masked in non-finite enclisis due to the affixal nature of non-finite morphology merged in $\mathrm{H}$. This is consistent with the well-known hypothesis that morphology precedes prosody.

One prediction of this analysis is that non-finite enclisis will pattern with finite enclisis if non-finite morphology is non-affixal, or if it is inserted in some head other than $\mathrm{H}$. Indeed, this appears to be the case in certain ToblerMussafia languages, including Medieval Greek and the (contemporary) Cretan dialect (see Condoravdi \& Kiparsky 2001, 2004; Pappas 2004), Bulgarian (see Pancheva 2005), or various stages of Old French (see Labelle \& Hirschbühler 2005). Focusing on Medieval Greek [MG], it has both preverbal and postverbal clitics with (true) imperatives, depending on the properties of the constituent preceding the clitic cluster (which is what we also find in CG finite enclisis). This is illustrated in (62) below, where a ría, presumably a preverbal stressed/emphasized adjectival predicate, triggers proclisis (62a), as opposed to próton, a preverbal adverbial topic, which triggers enclisis (62b):
a. Ayía tin ipé!
Holy.F.SG 3.F.SG.ACC call.IMP.2.SG
'Call her holy!' (example taken from Pappas 2004: 70 (his (57))

b. Próton ipé mas mana!

first tell.IMP.2.SG 1.PL.DAT mother.voc

'First, tell us mother ...' (example taken from Pappas 2004: 81 (his (16)) 
A straightforward way to account for this distribution is to assume that imperative verb forms are licensed in $\mathrm{T}$ and end $\mathrm{up}$ in $\mathrm{H}$ in case nothing else has merged there, on a par with finite morphology (see also Condoravdi \& Kiparsky 2004. For other languages, see Bošković 2004; Medeiros 2015; Pancheva 2005; Rivero \& Terzi 1995). Were this to be the case, we would expect (true) MG imperatives to behave like non-imperative forms in various respects. This prediction appears to be borne out, as illustrated by the following example of a (true) negated imperative (see Laka 1990; Han 1998; Zanuttini 1997 for negated imperatives):

(63) To thélimà mu plíroson ke apì̛is mi the wish.ACC 1.SG.GEN fulfil.IMP.2.SG and disobedient.NOM NEG

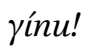

become.IMP.2.SG

'Fulfil my wish and do not become disobedient!' (from Condoravdi \& Kiparsky (2004: 170 (their (10)))

According to this analysis, CG and SG differ from MG in that in the former imperative morphology is inserted and spelled-out in $\mathrm{H}$ (along with $\mathrm{T}$, as it is affixal), while in the latter it is inserted and spelled-out in $\mathrm{T}$ (unless $\mathrm{T}$ is spelled out in $\mathrm{H}$ as a Last Resort, due to the Edge Requirement):

(64) a. $\left[{ }_{\mathrm{HP}} \mathrm{H}_{[\text {neg; foc; Ø] }}\left[{ }_{\mathrm{TP}} \mathrm{T}_{[+ \text {imp }]}\right]\right]$

b. $\left[{ }_{\mathrm{HP}} \mathrm{H}_{[+\mathrm{imp}]}[\mathrm{TP} \mathrm{T}]\right]$

(Medieval Greek imperatives) (CG \& SG imperatives)

In other words, the position of clitics can be parameterized wrt. the structural position a certain (functional) feature may be inserted at (in this respect, cf. infinitives in certain Italian dialects, which are reported by Manzini \& Savoia 2005 to pattern like MG imperatives and unlike standard Italian non-finite forms), in fact even within the same language (e.g. cf. MG gerunds, which according to Pappas 2004 trigger obligatory enclisis, on a par with $\mathrm{CG}$ and SG).20

There are at least two additional loci of parameterization predicted by this system. The first locus involves the (non-)affixal status of imperative/non-finite

20 In this respect, CG seems to have moved closer to SG, although it is far from clear whether this means it is likely to also lose finite enclisis in the future (cf. e.g. Bulgarian, which according to Pancheva 2005 changed from a SG-like system to a CG-like system). If the Edge Requirement is imposed on $\mathrm{H}$, then any changes in $\mathrm{H}$ (including its featural content) is expected to play a role in the transition. This is an issue for further research. Thanks to an anonymous reviewer for pointing out this issue to me. 
morphology. As far as I know, there is no Tobler-Mussafia language having a true imperative/non-finite non-affixal head that blocks enclisis (although suppletive heads, such as subjunctive or deontic modality negation particles, do have this function (see Isac \& Jakab 2004), in which case we would expect them to show root properties). This means that imperative/non-finite morphology in $\mathrm{H}$ will normally trigger enclisis. The second locus involves the Edge Requirement and where it applies ( $\mathrm{H}$ or some other head). In particular, if $\mathrm{H}=\mathrm{T}$ in morpho-syntactic and/or prosodic terms, we would get a language that lacks finite enclisis (cf. SG and most standard Romance languages). In this case, $\mathrm{T}$ would be predicted to have $\mathrm{H}$ properties, either morpho-syntactically and/or prosodically, with repercussions on the (A- vs. A-bar) nature of constituents merged in [Spec TP]. Although there seems to be evidence that T may indeed have morpho-syntactic and prosodic properties located in $\mathrm{H}$ in languages like SG (see, e.g., Alexiadou \& Anagnostopoulou 1998 on Greek A'-subjects; Richards 2016 on $\mathrm{T}$ being the edge of a prosodic domain in null subject languages), additional research is required to understand what the exact matching of morphosyntax and prosody is, and how it fits into the present theory. This is beyond the purposes of the current paper, so I leave it open for future research (Mavrogiorgos, in progress).

Summing up, in this section I argued that $\mathrm{H}$ seems to have an additional morphological/affixal requirement, as manifested by non-finite enclisis in CG, SG and MG. I also offered some speculative remarks on possible loci of parameterization for $\mathrm{H}$, which may account for the lack of finite enclisis in languages like SG.

\section{5 Conclusion}

The main claim of this paper was that CG and SG enclisis are amenable to a decompositional analysis of the EPP. In particular, $\mathrm{H}$, the first head c-selecting TP (presumably the locus of theme-rheme division), contains an unvalued morpho-syntactic feature that AG REES with a matching $\mathrm{X}$ or XP item. $\mathrm{H}$ also has a contingent $P F$ requirement imposed on it (the Edge Requirement), according to which $\mathrm{H}$ must be spelled-out locally and only once by a non-affixal (X or XP) item. This derives the complementary distribution pattern attested in CG finite enclisis and MG imperative enclisis, as well as the lack thereof in CG and SG non-finite enclisis. The novelty of this approach is that in order to account for finite enclisis it postulates a PF part for the EPP (see also Revithiadou 2006, 2007 and fn 18 for CG; for Western Iberian see Raposo \& Uriagereka 2005) that applies to a very specific structural position $(\mathrm{H})$, contrary to the majority of the 
available literature, which assumes that the EPP is purely morpho-syntactic in nature, potentially applying to any feature within any functional head (see, e.g., Rivero \& Terzi 1995, and Terzi 1999a,b for CG; Benincá 2006; Poletto 2014 for Old Italian and Medieval Romance; Fernández-Rubiera 2013 for Asturian; Roberts 2012 for Tobler-Mussafia languages and Slavic languages). One advantage of the current approach is that it derives all the attested patterns on the basis of a wellgrounded hypothesis (see Landau 2007; see also Mavrogiorgos, in progress, for additional evidence in favour of a local PF EPP). A second advantage is that the hypothesis that the EPP applies to $\mathrm{H}$ is simpler and more easily falsifiable, compared to an approach that postulates that the EPP is a feature potentially applying to any functional head/feature (as, e.g., Landau 2007). From an empirical point of view, an equally important contribution is that it sets apart proclisis triggers from enclisis triggers in terms of their hierarchical position in the clausal structure. This approach is novel, and has led to the empirical generalization in section 3.2 .2 and to the formulation of an explicit theoretical hypothesis about the EPP vis-à-vis clausal architecture. Moreover, it has direct implications for the status of non-stressed preverbal subjects in CG as topics (which could be informative also for SG, which lacks finite enclisis), as they behave like preverbal object topics with respect to enclisis (which, in turn, predicts that they should have additional topic properties, such as referentiality and wide scope, and moreover that subjects lacking these properties would trigger proclisis). ${ }^{21}$ Further issues arise at this point: how is CG enclisis related to second position cliticization or to V2 phenomena, which also involve a C-T interaction vis-à-vis the EPP?; are there other domains with the same EPP requirement, and if yes, what are these and what are their properties? ${ }^{22}$ Although these issues are relevant to the proposed analysis, they cannot be addressed appropriately within the limits of the current paper.

\section{References}

Agouraki, Yoryia. 1997. On the enclisis/proclisis alternation. Proceedings of the Second International Conference on Greek Linguistics, vol. II, University of Salzburg, ed. by Gaberell Drachman, Angeliki Malikouti-Drachman, Yiorgos Fykias, Cyla Klidi, 393404. Graz: Neugebauer.

\footnotetext{
21 These predictions are open for further research. I would like to thank an anonymous reviewer for making this point clear to me.

22 I would like to thank an anonymous reviewer for pointing out this issue to me.
} 
Agouraki, Yoryia. 2001. The position of clitics in Cypriot Greek. Proceedings of the First International Conference on Modern Greek Dialects and Linguistic Theory, ed. by Angeliki Ralli, Brian Joseph, Mark, Janse, 1-18. Patras; University of Patras.

Agouraki, Yoryia. 2010. It-clefts and stressed operators in the preverbal field of Cypriot Greek. Lingua 120. 527-554.

Alexiadou, Artemis \& Elena Anagnostopoulou. 1997. Toward a uniform account of scrambling and clitic doubling. German: Syntactic Problems-Problematic Syntax, ed. by Werner Abraham, Elly van Gelderen, 142-161. Max Niemeyer: Tübingen.

Alexiadou, Artemis \& Elena Anagnostopoulou. 1998. Parametrizing Agr: Word order, vmovement and E P P-checking. Natural Language and Linguistic Theory 16. 491-539.

Anagnostopoulou, Elena. 1997. Clitic Left Dislocation and Contrastive Left Dislocation. Materials on Left Dislocation, ed. by Elena Anagnostopoulou, Henk van Riemsdijk, \& Frank Zwarts, 151-192 Amsterdam: John Benjamins.

Anagnostopoulou, Elena. 2003. The Syntax of Ditransitives. Evidence from Clitics. Berlin: Mouton de Gruyter.

Benincà, Paola. 2006. A detailed map of the left periphery of Medieval Romance. Crosslinguistic Research in Syntax and Semantics. Negation, Tense, and Clausal Architecture, ed. by Raffaella Zanuttini, Héctor Campos, Elena Herburger, \& Paul Portner, 53-86. Washington, DC: Georgetown University Press.

Bošković, Zeljko. 2001. On the Nature of the Syntax-Phonology Interface. Cliticization and Related Phenomena. Amsterdam: Elsevier.

Bošković, Zeljko. 2004. On the clitic switch in Greek imperatives. Balkan Syntax and Semantics, ed. by Olga Miseska Tomić, 269-291. Amsterdam: John Benjamins.

Chatzikyriakidis, Stergios. 2010. Clitics in 4 Dialects of Modern Greek: A Dynamic Account. PhD thesis, King's College, London.

Chatzikyriakidis, Stergios. 2012. A Dynamic Account of the Cypriot Greek Clitic Positioning system. Lingua 122. 642-672.

Chomsky, Noam. 1981. Lectures on Government and Binding. Dordrecht: Foris.

Chomsky, Noam. 200o. Minimalist inquiries: The framework. Step by Step: Essays on Minimalist Syntax in Honor of Howard Lasnik, ed. by Roger Martin, David Michaels, Juan Uriagereka \& Samuel Jay Keyser, 89-155. Cambridge, MA: The Miт Press.

Chomsky, Noam. 2001. Derivation by phase. Ken Hale: A Life in Language, ed. by Michael Kenstowicz, $1-52$. Cambridge, MA: The Miт Press.

Chomsky, Noam., Lasnik, Howard. 1977. Filters and Control. Linguistic Inquiry 8. 425504.

Christodoulou, Christiana \& Martina Wiltschko. 2012. Function without content: Evidence from Greek subjunctive na. Towards a Biolinguistic Understanding of Grammar: Essays on Interfaces, ed. by Ana Maria Di Sciullo, 117-140. Amsterdam: John Benjamins.

Collins, Chris. 2007. Home Sweet Home. NYU Working Papers in Linguistics 1. 1-34. 
Condoravdi, Cleo \& Paul Kiparsky. 2001. Clitics and clause structure. Journal of Greek Linguistics 2. 1-40.

Condoravdi, Cleo \& Paul Kiparsky. 2004. Clitics and Clause structure. The Late Medieval Greek system. Journal of Greek Linguistics 5. 159-183.

Embick, David. 200o. Features, Syntax, and Categories in the Latin Perfect. Linguistic Inquiry $3,185^{-23}$.

Emonds, Joseph. 2004. Unspecified categories as the key to root constructions. Peripheries: Syntactic Edges and their Effects, ed. by David Adger, Cecilia de Cat \& George Tsoulas, $75^{-120}$. Netherlands: Springer.

Fernández-Rubiera, Francisco. 2013. Root and embedded contexts in Western Iberian. Challenging Clitics, ed. by Christine Meklenborg Salvesen \& Hans Peter Helland, $55^{-}$ 86. Amsterdam: John Benjamins.

Franks, Steven. 2015. Clitics are/become Minimal(ist). Ms, Indiana University Bloomington.

Grohmann, K. Kleanthes, John Drury, \& Juan Carlos Castillo. 20oo. No more EPP. WCCFL 19 Proceedings, 153-166, ed. by Roger Billerey \& Brook Danielle Lillehaugen, 153-166. Somerville, MA: Cascadilla Press.

Han, Chung-hye. 1998. The Structure and Interpretation of Imperatives: Mood and Force in Universal Grammar. PhD thesis, University of Pennsylvania.

Halpern, Aaron. 1995. On the Placement and Morphology of Clitics. CsLI: Stanford CA.

Holmberg, Anders. 2000. Scandinavian Stylistic Fronting. How Any Category Can Become An Expletive. Linguistic Inquiry 31. 445-483.

Iatridou, Sabine. 1991. Clitics and Island Effects. Ms., MIT.

Iatridou, Sabine \& Anthony Kroch. 1992. The licensing of CP-recursion and its relevance to the Germanic verb-second phenomenon. Working Papers in Scandinavian Linguistics 50. 1-25.

Isac, Daniella \& Edit Jakab. 2004. Mood and Force Features in the Languages of the Balkans. Balkan Syntax and Semantics, ed. by Olga Miseska Tomić, 315-339. Amsterdam: Benjamins.

Klavans, Judith. 1985. The Independence of Syntax and Phonology in Cliticization. Language 61. 95-120.

Koopman, Hilda. 200o. The Syntax of Specifiers and Heads. Routledge, London.

Kupula, Mikko. 2011. A phase-extension approach to double object constructions: Evidence from Modern Greek. Studia Linguistica 65. 147-169.

Labelle, Marie \& Paul Hirschbühler. 2005. Changes in Clausal Structure and the Position of Clitics in Old French. Grammaticalization and Parametric Variation, ed. by Montserrat Batllori, Maria-Lluïsa Hernanz, Carme Picallo, \& Francesc Roca, 149-178. Oxford: Oxford University Press.

Laka, Itziar. 199o. Negation in Syntax: On the Nature of Functional Categories and Projections. PhD thesis, MIT. 
Landau, Idan. 2006. Chain resolution in Hebrew V(P)-fronting. Syntax 9. 32-66.

Landau, Idan. 2007. E PP extensions. Linguistic Inquiry 38. 485-523.

Lasnik, Howard. 1995. Verbal morphology: Syntactic Structures meets the Minimalist Program. Evolution and revolution in linguistic theory: Essays in honor of Carlos Otero, ed. by Héctor Campos \& Paula Kempchinsky, 251-275. Washington D.c.: Georgetown University Press.

Lasnik, Howard. 2003. On the Extended Projection Principle. Studies in Modern Grammar 31. 1-23.

Lechner, Winnie. 2007. Interpretative effects of head movement. Ms., University of Athens. lingbuzz/ooo178.

Manzini, Rita \& Leonardo Maria Savoia. 2002. Parameters of Subject Inflection in Italian Dialects. Subjects, Expletives, and the EPP, ed. by Peter Svenonius, 157-199. New York: Oxford University Press.

Manzini, Rita \& Leonardo Maria Savoia. 2005. Idialetti italiani e romanci. Morfosintassi generativa. 3 vols. Alessandria: Edizioni dell'Orso.

Mavrogiorgos, Marios, 2010. Clitics in Greek: A Minimalist Account of Proclisis and Enclisis. Amsterdam: John Benjamins.

Mavrogiorgos, Marios. 2013. Enclisis at the Syntax-PF Interface. Challenging Clitics, ed. by Christine Meklenborg-Salvesen \& Hans Peter Helland, 27-54. Amsterdam: John Benjamins.

Mavrogiorgos, Marios. in progress. Clitic positioning and the interfaces. Ms., University of Cambridge.

Medeiros, David. 2015. Embedded Ancient Greek Imperatives: A Feature Transfer Analysis. Syntax 18. 124-156.

Meinunger, André. 2006. Interface restrictions on verb second. The Linguistic Review 23. 127-16o.

Merchant, Jason, Pavlou, Natalia. this volume. The morphosyntax of the periphrastic future under negation in Cypriot Greek. Journal of Greek Linguistics 17.2 (2017).

Mohr, Sabine. 2009. V2 as a Single-Edge phenomenon. Selected Papers from the 2006 Cyprus Syntaxfest, ed. by Kleanthes K. Grohmann \& Phoevos Panagiotidis, 141-158. Newcastle: Cambridge Scholars Publishing.

Nchare, Abdoulaye Laziz \& Arhonto Terzi. 2014. Licensing silent structure: the spatial prepositions of Shupamem. Natural Language and Linguistic Theory 32. 673-710.

Pancheva, Roumyana. 2005. The Rise and Fall of Second Position Clitics. Natural Language and Linguistic Theory 23. 103-167.

Pappas, Panayiotis. 2004. Variation and Morphosyntactic Change in Greek. From Clitics to Affixes. New York: Palgrave Macmillan.

Pearson, Matthew. 2005. The Malagasy Subject/Topic as an A'-Element. Natural Language and Linguistic Theory $23 \cdot 381-457$.

Pesetsky, David. 1998. Some Optimality Principles of Sentence Pronunciation. Is the 
Best GoodEnough?, ed. by Barbosa Pilar, Daniel Fox, Paul Hagstrom, Martha McGinnis, \& David Pesetsky, 337-383. Cambridge, MA: The мiт Press.

Pesetsky David \& Esther Torrego. 2001. T-to-C movement: Causes and consequences. Ken Hale. A Life in Language, ed. by Michael Kenstowicz, 355-426. Cambridge, MA: The Mit Press.

Philippaki-Warburton, Irene. 1992. On mood and complementizers in Modern Greek. Reading University Working Papers in Linguistics $1.5^{-41}$.

Philippaki-Warburton, Irene. 1995. Metakinisi rimatos ke i katanomi ton klitikon antonimion. Studies in Greek Linguistics 15. 892-905.

Philippaki-Warburton, Irene. 1998. Functional categories and Modern Greek syntax. The Linguistic Review 15. 159-186.

Platzack, Christer. 2010. Head Movement as a Phonological Operation. Ms., Lund University.

Poletto, Cecilia. 2014. Word Order in Old Italian. Oxford: Oxford University Press.

Raposo, Eduardo, Uriagereka, Juan. 2005. Clitic placement in Western Iberian. The Oxford handbook in comparative syntax, ed. by Guglielmo Cinque \& Richard Kayne, 639-697. Oxford: Oxford University Press.

Revithiadou, Anthi. 20o6. Prosodic filters on syntax: an interface account of second position clitics. Lingua 116. 79-111.

Revithiadou, Anthi. 2007. A cross-dialectal study of cliticisation in Greek. Lingua 118. 1393-1415.

Richards, Norvin. 2010. Uttering Trees. Cambridge, ma: The mit Press.

Richards, Norvin. 2016. Contiguity Theory. Cambridge, MA: The MIT Press.

Ritter, Elisabeth \& Martina Wiltschko. 20o9. Varieties of INFL: TENSE, LOCATION and PERSOn. Alternatives to cartography, ed. by Jeroen van Craenenbroeck, 153-201. Berlin: Mouton de Gruyter.

Rivero, Maria-Luisa. 1994. Clause structure and V-movement in the languages of the Balkans. Natural Language and Linguistic Theory 12. 63-120.

Rivero, Maria-Luisa \& Arhonto Terzi. 1995. Imperatives, v-movement and logical mood. Journal of Linguistics 31. 301-322.

Rizzi, Luigi. 1996. Residual Verb Second and the Wh-criterion. Parameters and Functional Heads, ed. by Adriana Belletti \& Luigi Rizzi, 63-9o. Oxford: Oxford University Press.

Rizzi, Luigi. 1997. The fine structure of the left periphery. Elements of Grammar. A Handbook in Generative Syntax, ed. by Liliane Haegeman, 281-337. Dordrecht: Kluwer.

Roberts, Ian. 2010. Agreement and Head Movement. Cambridge, MA: The Mit Press. Roberts, Ian. 2012. Phases, head movement and second-position effects. Phases. Developing the Framework, ed. by Ángel Gallego, 385-440. Berlin: Mouton de Gruyter.

Roberts, Ian, Roussou, Anna. 2002. The extended projection principle as a condition 
on the tense-dependency. Subjects, Expletives, and the EPP, ed. by Peter Svenonius, 125-156. New York: Oxford University Press.

Roussou, Anna. 2000. On the left periphery: modal particles and complementisers. Journal of Greek Linguistics 1. 65-94.

Schütze, Carson. 2004. Serbo-Croatian second position clitic placement and the phonology-syntax interface. MIT Working Papers in Linguistics 21. Papers on Phonology and Morphology, ed. by Andrew Carnie, Heidi Harley, \& Tomas Bures, 373-473. Cambridge, MA: Department of Linguistics and Philosophy, MIт.

Selkirk, Elisabeth. 2011. The Syntax-Phonology Interface. The Handbook of Phonological Theory, Second Edition, 435-484, ed. by John A. Goldsmith, Jason Riggle, \& Alan C.L. Yu, 435-484. Oxford: Blackwell.

Sigurđsson, Halldór-Ármann. 2010. On EPP effects. Studia Linguistica 64. 159-189.

Speas, Margaret. 1995. Economy, Agreement, and the Representation of Null Arguments. Ms. UMass.

Sportiche, Dominique. 1992/1998. Clitic constructions, Ms. (1992). Published as Chapter 4 in: Partitions and Atoms of Clause Structure: Subjects, Agreement, Case and Clitics, 244-307. London: Routledge.

Terzi, Arhonto. 1999a. Clitic combinations, their hosts and their ordering. Natural Language and Linguistic Theory $17.85^{-121 .}$

Terzi, Arhonto. 1999b. Cypriot Greek clitics and their positioning restrictions. Studies in Greek Syntax, ed. by Artemis Alexiadou, Geoffrey Horrocks, \& Melita Stavrou, 227240. Dordrecht: Kluwer.

Truckenbrodt, Hubert. 2006. On the semantic motivation of syntactic verb movement to $\mathrm{C}$ in German. Theoretical Linguistics 32-33. 257-306.

Zanuttini, Raffaella. 1997. Negation and Clausal Structure: A Comparative Study of Romance Languages. Oxford: Oxford University Press.

Zwart, Jan-Wouter. 2001. Syntactic and Phonological Verb Movement. Syntax 4. 34-62. Zwart, Jan-Wouter. 2005. Verb second as a function of merge. The Function of Function Words and Functional Categories, ed. by Marcel den Dikken \& Christina Tortora, 1140. Amsterdam: John Benjamins. 